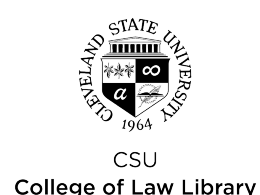

Cleveland State University

College of Law Library

\title{
EngagedScholarship@CSU
}

\section{Faith-Based Financial Regulation: A Primer on Oversight of Credit Rating Organizations}

Christopher L. Sagers

Cleveland State University, c.sagers@csuohio.edu

Thomas J. Fitzpatrick

Follow this and additional works at: https://engagedscholarship.csuohio.edu/fac_articles

Part of the Banking and Finance Law Commons

How does access to this work benefit you? Let us know!

\section{Original Citation}

Christopher Sagers, Faith-Based Financial Regulation: A Primer on Oversight of Credit Rating Organizations, 61 Administrative Law Review 557 (2009)

This Article is brought to you for free and open access by the Faculty Scholarship at EngagedScholarship@CSU. It has been accepted for inclusion in Law Faculty Articles and Essays by an authorized administrator of EngagedScholarship@CSU. For more information, please contact research.services@law.csuohio.edu. 


\section{HEINONLINE}

Citation: 61 Admin. L. Rev. 5572009

Content downloaded/printed from

HeinOnline (http://heinonline.org)

Tue May 22 09:40:26 2012

-- Your use of this HeinOnline PDF indicates your acceptance of HeinOnline's Terms and Conditions of the license agreement available at http://heinonline.org/HOL/License

-- The search text of this PDF is generated from uncorrected OCR text.

-- To obtain permission to use this article beyond the scope of your HeinOnline license, please use:

https://www.copyright.com/ccc/basicSearch.do?

\&operation $=$ go\&search Type $=0$

\&lastSearch $=$ simple\&all $=$ on\&titleOrStdNo $=0001-8368$ 


\title{
FAITH-BASED FINANCIAL REGULATION: A PRIMER ON OVERSIGHT OF CREDIT RATING ORGANIZATIONS
}

\author{
THOMAS J. FITZPATRICK, IV* \\ CHRIS SAGERS ${ }^{* *}$
}

\section{TABLE OF CONTENTS}

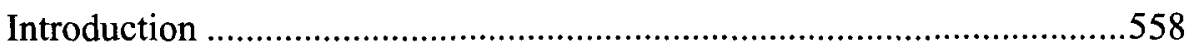

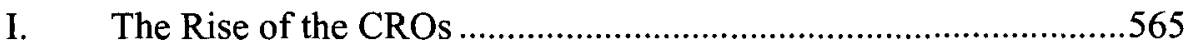

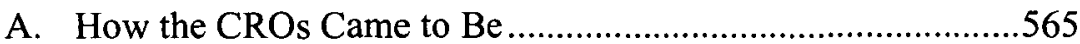

B. How They Do What They Do..............................................573

II. The Entangled Growth of Innovation, Disintermediation, and

Deregulation ............................................................................576

III. Overarching Problems: The Economics of Information and the Missing Evidence of Value...........................................................581

IV. Other Overarching Problems with the CROs as They Exist...........586

A. Conflicts of Interest ............................................................586

B. Doubts About "Reputational Capital" ...................................589

C. Resource Constraints: Coping with Complexity and Rapid

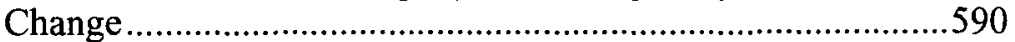

V. What Constraints at Present? ....................................................592

A. Big-Picture Basics, or What Exactly Are the CROs? ...............592

1. Are CROs the "Government"? ........................................592

2. On the Contrary, They Are Just Regular Folks Speaking Their Minds

- Economist, The Federal Reserve Bank of Cleveland. This Article reflects the views of the authors only and not necessarily those of the Board of Governors, the Federal Reserve Bank of Cleveland, or other banks in the Federal Reserve System.

** Associate Professor of Law, Cleveland State University. For his uncommonly generous review and thoughtful insights, our special thanks to James Thomson of the Federal Reserve Bank of Cleveland. Thanks as well for feedback on earlier drafts to Peter Carstensen, Mark Greenlee, Alan Palmiter, and participants in a panel session at the 2009 Law \& Society Association annual meeting. We welcome all feedback at thomas.j.fitzpatrick@clev.frb.org and csagers@law.csuohio.edu. 
3. But Are They Standard Setters?.

B. CRARA and SEC Oversight: Free-Market Competition

Solutions Are Doomed ........................................................595

C. International and Self-Regulatory Initiatives..........................598

D. Civil Liability ...................................................................599

1. Federal Securities Regulation .......................................599

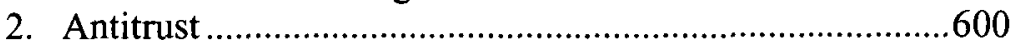

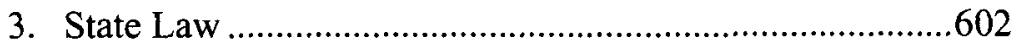

VI. Likely Future Unregulability ......................................................603

A. Real Free-Market Solutions: Adopt Investor-Pays or

Displace Intermediation Altogether.......................................603

B. Other Market Solutions, Sort of: Skin in the Game and Investor-Controlled CROs .......................................................604

C. The Last Market Solution, We Promise: Internalize Risk Externalities 606

D. Anti-market Solutions: Substance Regulation or Outright Socialization of Analytical Intermediation .607

Tentative Conclusions 609

\section{INTRODUCTION}

In light of the present economic crisis and their role in it, the world seems suddenly keen to know more about the handful of private corporations-variously known as bond rating agencies, credit rating agencies, credit rating organizations (CROs), or the like-that rate the creditworthiness of corporate and government debt securities. By most accounts, these companies hold extensive sway in public capital markets, and for about thirty years, a few of them have enjoyed literally de jure delegation of federal regulatory oversight over much of the U.S. financial sector. With that power their ratings have value regardless of their accuracy, and they have used this power to earn substantial profits. The regulatory use of credit ratings is particularly troubling because the CROs have been implicated in some of that sector's worst problems and, by most accounts, were intimately tied up in the present mess.

Despite the CROs' privileged status, they have never been especially popular with observers, and during the past several years, they have increasingly been blamed for financial-sector failures. In particular, they have been blamed for failing to warn of major bond defaults since at least the mid-1970s, the calamitous losses throughout the 1990s associated with various derivative products, and the corporate collapses of 2001 and $2002 .{ }^{1}$ Some observers see them as actively complicit in the current meltdown in

1. See infra notes $9,53-54$ and accompanying text (recounting the numerous alleged failings of CROs). 
structured finance. ${ }^{2}$ Possibly for the first time, CRO insiders are now blowing the whistle on what appears to have been significant internal wrongdoing. ${ }^{3}$

A flurry of U.S. government investigation has surrounded the CROs during the past two decades, ${ }^{4}$ and overseas they are under scrutiny by

2. See infra note 56 and accompanying text.

3. Notably, two former high-level executives of the ratings firm Standard \& Poor's (S\&P), Frank Raiter and Richard Gugliada, spoke candidly with documentary news reporters acknowledging that while the CROs could not meaningfully predict the soundness of many structured products, they rated them anyway because rating them was so profitable. NOW: Credit and Credibility (PBS television broadcast Dec. 26, 2008) (transcript available at http://www.pbs.org/now/shows/446/transcript.html). Raiter, in particular, confided that his entire department of analytical experts believed that some structured finance ratings were "guess[es]" and doubted that some of them could really be making money at all "because the general premise to some of us behind what [these products] were-was a mystery." Id. Their accounts are supported by anecdotal but fairly glaring evidence turned up by the Securities and Exchange Commission (SEC) staff in 2008, which included internal correspondence among analysts at the CROs indicating their doubts about their ratings of structured products, as well as evidence of substantial pecuniary conflicts of interest affecting analytical personnel. See SEC, SUMMARY REPORT OF ISSUES IDENTIFIED IN THE COMmission STAFF's EXAMINATIONS OF SELECT CREDIT RATING AGENCIES (2008), available at http://www.sec.gov/news/studies/2008/craexamination070808.pdf [hereinafter SEC 2008 STAFF REPORT].

4. Congress and the SEC have been investigating the CROs off and on since at least the late $1980 \mathrm{~s}$. With the exception of the light regulatory touch applied in legislation and rules that took effect in mid-2007, the chief result of all that work was just published criticism of the agencies. In light of the recent crisis and their apparently central role in it, both Congress and the SEC have recently undertaken major new regulatory steps. First, the Congressional Oversight Panel, a commission of outside experts established by the Troubled Asset Relief Program (TARP) legislation, recently released a report scathingly critical of deregulation and reliance on private-sector forces to constrain risk. See CONG. OVERSIGHT PANEL, SPECIAL REPORT ON REgULATORY REFORM: MODERNIZING THE AMERICAN FINANCIAL REgulatory System; Recommendations for ImPRoving OVERSight, Protecting CONSUMERS, AND ENSURING STABILITY (2009), available at http://cop.senate.gov/documents/cop-012909-report-regulatoryreform.pdf [hereinafter COP REPORT 2009]. Among other things, the report recommends creation of a government Credit Rating Review Board that would audit ratings and actively oversee the CROs. Id. at 44 . The SEC also undertook a major investigation of the CROs' practices immediately after the beginning of the subprime meltdown, producing one of the best exposés of the CROs' inner workings, especially of their function during the structured finance era. See SEC, REPORT on the Role and Function of CRedit Rating Agencies in the Operation of the SECURITIES MARKETS (2003), available at http://www.sec.gov/news/studies/credratingreport0103.pdf. The SEC has also issued a new set of proposed rules that, although still pending, appear to be more invasive than anything undertaken before. See Nationally Recognized Statistical Rating Organizations, 73 Fed. Reg. 36,212 (proposed June 25, 2008) (to be codified at 17 C.F.R. pts. 240 \& 249b) (enhancing the disclosure and comparability of credit rating performance statistics).

Until recently, state governments have mainly stayed out of the CROs' affairs, with the limited exception that state tort claims have sometimes been asserted by disappointed investors and issuers. See infra note 179 and accompanying text. In light of the recent crisis, however, the Attorney General of Connecticut has sued the CROs in antitrust on behalf of Connecticut municipalities injured by the ratings process for their debt issues. See infra note 9. Further, the Attorneys General of Ohio and New York have both begun investigations of the CROs' role in both subprime lending abuses and the larger credit crisis 
several intergovernmental ${ }^{5}$ and nongovernmental organizations. ${ }^{6}$ Much of

generally. See Katie Benner \& Adam Lashinsky, Subprime Contagion?, FORTUNE, July 23, 2007, available at http://money.cnn.com/2007/07/05/news/economy/subprime.fortune/ index.htm?postversion $=2007070511$; Press Release, Conn. Attorney General's Office, Attorney General Says His Broader Investigation into Credit Rating Agencies Continuing Aggressively (June 5, 2008), http:/www.ct.gov/ag/cwp/view.asp?A=2795\&Q=416772; Press Release, Office of the Attorney General of N.Y., Attorney General Cuomo Announces Landmark Reform Agreements with the Nation's Three Principal Credit Rating Agencies (June 5, 2008), http://www.oag.state.ny.us/media_center/2008/jun/june5a_08.html.

The Government Accountability Office (GAO) has been a frequent critic, and a harsh one lately. See Gov. Accountability Office, Financial Regulation: A Framework for Crafting and AsSEssing Proposals to Modernize the OUTdated U.S. FINANCIAL REGULATORY SYSTEM 30-32 (2009), available at http://www.gao.gov/new.items/d09216.pdf (asserting that the existing regulatory system has failed to identify and manage the risks associated with CROs). More generally, GAO has argued since at least the early 1990 s that U.S. financial regulation is dangerously fragmented and uncoordinated, and has repeatedly urged various reforms, although to little avail. See generally Gov. ACCOUNTABILITY OfFICE, FINANCIAL REgulation: INDUSTRY Trends CONTINUE to CHALlENGE THE FedERAL REgulatory STRUCTURE (2007), available at http://www.gao.gov/new.items/d0832.pdf; Gov. ACCOUNTABILITY OFFICE, FINANCIAL Regulation: Industry Changes Prompt NeEd to Reconsider U.S. Regulatory STRUCTURE (2004), available at http://www.gao.gov/new.items/d0561.pdf; Testimony Before the Comm. on Banking and Financial Servs., 104th Cong. (1995) (statement of James L. Bothwell, Director, Financial Institutions and Markets Issues, General Government Division, Government Accountability Office), available at http://www.gao.gov/archive/1996/gg96117t.pdf; Testimony Before the Subcomm. on Capital Markets, Securities and GSEs, House Comm. on Banking and Financial Servs., 104th Cong. (1995) (statement of James L. Bothwell, Director, Financial Institutions and Markets Issues, General Government Division, Government Accountability Office), available at http://archive.gao.gov/t2pbat1/154163.pdf.

5. Several intergovernmental coalitions have taken acute interest in the CROs, especially in the wake of the present crisis. The thrust of their efforts has been to develop a body of hortatory guidance to better contain the CROs' misbehavior, mostly consisting of structural tweaks and disclosure rules to improve transparency.

There are a few important recent efforts. First, an April 2008 report of the Financial Stability Forum (FSF), a task force of the Group of Seven finance ministers, placed CROs at the heart of the crisis, particularly for their role in structured finance products. The FSF recommended substantially revised ratings methodologies and conduct standards, and recommended reconsideration of the use of CROs' ratings in regulation. These recommendations were in addition to a raft of other recommendations to improve system-wide transparency and risk management. See FIN. STABILITY FORUM, REPORT OF THE Financial Stability Forum ON ENHANCING MaRKET and INSTITUTIONAL REsILIENCE 5-11, 32-39 (2008), available at http://www.fsforum.org/publications/r_0804.pdf [hereinafter FSF 2008 REPORT] (discussing the underlying causes and weaknesses and recommendations to address them). Second, an international consortium of regulators, the International Organization of Securities Commissions (IOSCO), first attempted to address some of the CROs' problems in 2004 and then studied the problem anew in the wake of the credit crisis. See TECHNICAL COMM., INT'L ORG. OF SECS. COMM'NS, CODE OF CONDUCT FundaMENTALS FOR CREDIT RATING AGENCIES (2004), available at http://www.iosco.org/library/pubdocs/pdf/IOSCOPD180.pdf, for the initial report. See TECHNiCal COMm., INT'L ORg. OF SECS. COMm'NS, The Role OF Credit Rating Agencies IN STRUCTURED FINANCE MARKETS: FINAL REPORT (2008), available at http://www.iosco.org/library/pubdocs/pdf/IOSCOPD270.pdf, for the final report. Third, the Committee of European Securities Regulators (CESR), a task force of European Union regulators set up to advise the European Commission (EC), has actively monitored the 
the domestic soul-searching has been driven by the outright delegation of federal regulatory power and virtually nonexistent legal oversight. ${ }^{7}$ Aside from a fleeting and uneventful antitrust investigation in the late $1990 \mathrm{~s},{ }^{8}$ the

CROs for years, but so far has only urged that CROs voluntarily adopt the CROs' code of conduct. CESR has affirmatively urged the EC not to regulate the CROs. See COMM. OF EuROPEAN SECS. REgulators, CESR'S TECHNICAL AdVICE to THE EUROPEAN COMMISSION on Possible Measures CONCERNing Credit Rating Agencies 52 (2005), available at http://www.cesr.eu. Fourth, the Bank for International Settlements' Basel Committee has studied the CROs fairly extensively and recommended reforms. See COMM. ON THE GLOBAL Fin. Sys., BANK FOR INT'L SETtlements, The Role of RATINGS In STRUCTUREd FinanCE: ISSUES AND IMPLICATIONS (2005), available at http://www.bis.org/publ/cgfs23.pdf [hereinafter BIS STRUCTURED FINANCE REPORT]. But more ominously, the Bank's Basel Committee on Banking Supervision (Basel Committee), whose guidance efforts have largely laid the foundation for current capital market structure, has recommended international adoption of the American model of credit assessment. As will be explained more fully later in this Article, for many years U.S. regulation has made use of CROs' ratings by incorporating them by reference in a variety of mandatory rules imposed on financial institutions. The Basel accord currently in force contemplates adopting such a system worldwide. The Basel Committee's approach, inasmuch as it invites all the problems of the American one, has been the focus of harsh criticism. See, e.g., Lawrence J. White, The Credit Rating Industry: An Industrial Organization Analysis, in Ratings, Rating AgEnCies and the Global FinAnCIal System 41 (Richard M. Levich et al. eds., 2002).

Some other international efforts have addressed the CROs but with somewhat different purposes and likely effects. For example, the Association of South East Asian Nations (ASEAN) Forum on Credit Rating Agencies, an intergovernmental group of South Asian countries, adopted a hortatory code of ethics for CROs in those countries, but the code seems mainly driven by the countries' desire to grow domestic ratings industries. The code evinces little concern for investors or substantive quality. See TIMOTHY J. SINCLAIR, The New Masters of Capital: american Bond Rating Agencies and the Politics of CREDITWORTHINESS 125-26(2005).

6. Notably, the International Group of Treasury Associations (IGTA), a coalition of a few dozen national trade associations for corporate finance professionals, collectively representing tens of thousands of financial managers on both the buyer and issuer sides, has lobbied the SEC for some time for stricter regulation of CROs. See Press Release, Ass'n for Fin. Prof'ls, Thirty International Treasurers Organizations Urge SEC to Act Now on Credit $\begin{array}{lllll}\text { Rating Agency } & \text { Reform 2004), }\end{array}$ http://www.afponline.org/pub/pr/2004/pr_20041208_igta.html. IGTA, along with its member organizations from the United States, United Kingdom, and France, has also developed a hortatory ethical code for CROs. See ASS'N FOR CORPORATE TREASURERS ET al., CODE of Standard Practices for Participants in the Credit Rating Process (2005), available at http://www.afponline.org/pub/pdf/CSP_final.pdf. The drafters noted their general support for the previously issued IOSCO Code, and intend the IGTA Code to be a complement to the IOSCO Code. Id. at vii-viii.

7. See infra notes 24-32 and accompanying text (discussing the CROs' role in federal regulation of securities and banking markets).

8. The Antitrust Division of the U.S. Department of Justice has long had an eye on the CROs and formally investigated Moody's in the late 1990s on suspicion that it penalized issuers who used other services by issuing them unsolicited and improperly low ratings. The Antitrust Division ended its inquiry in 1999 without taking any antitrust action. See Charles Gasparino, Inquiry into Moody's Ratings Practices Ends as U.S. Agency Takes No Action, WALL ST. J., Mar. 12, 1999, at A4. Though an antitrust suit was not filed, Moody's pleaded guilty in 2001 to obstruction of justice in that investigation, admitting that it destroyed damning documents relevant to the investigation. Moody's paid nearly $\$ 200,000$ 
federal government never directly regulated the powerful, hundred-year-old industry until June 2007. However, even the 2007 effort imposed virtually no constraints. ${ }^{9}$

Current circumstances have shaken faith in the CROs, and the question seems not whether the regulatory approach will change, but only how much, in what ways, and with what consequences. Several academic endeavors are afoot to understand the CROs better, ${ }^{10}$ and many of them

and agreed to three executive resignations to settle the matter. See Queena Sook Kim, Moody's Pleads Guilty to Destroying Documents During Antitrust Investigation, WaLL ST. J., Apr. 11, 2001, at B8. Moody's conduct also resulted in unsuccessful antitrust litigation by an issuer that claimed Moody's penalized it with a lowered bond rating when the issuer chose to use a lower priced CRO. See Jefferson County Sch. Dist. No. R-1 v. Moody's Investor's Servs., Inc., 175 F.3d 848 (10th Cir. 1999). Late last year, apparently in response to the meltdown in subprime mortgage-backed securities, Connecticut's Attorney General opened a new investigation, which focused on the CROs' alleged ability to charge supracompetitive prices to Connecticut municipal bond issuers for ratings services. See Rupini Bergstrom, Bond Raters Get Subpoenas: Connecticut Presses Antitrust Inquiry; Firms Cooperating, WALL ST. J., Oct. 27-28, 2007, at B2. In July 2008, the investigation resulted in the first of several planned suits against the CROs. See Press Release, Conn. Attorney General's Office, Attorney General Sues Credit Rating Agencies for Illegally Giving Municipalities Lower Ratings, Costing Taxpayers Millions (July 30, 2008), http://www.ct.gov/ag/cwp/view.asp?a=2795\&q=420390.

9. After years of study and agitation, Congress finally adopted legislation to regulate the CROs in 2006. See Credit Rating Agency Reform Act of 2006, Pub. L. No. 109-291, § 4(a), 120 Stat. 1329 (2006) (codified at 15 U.S.C. $\$ 780-7$ (2006)). The Credit Rating Agency Reform Act of 2006 (CRARA) was adopted explicitly in response to the collapse of Enron and other corporate failures in 2001 and 2002, and to the CROs' perceived role in them. See S. REP. No. 109-326, at 1-2 (2006), reprinted in 2006 U.S.C.C.A.N. 865, 86566. Because CRARA depends on voluntary registration, it had little real effect before its implementation by SEC rules in June 2007. See Oversight of Credit Rating Agencies Registered as Nationally Recognized Statistical Rating Organizations, 72 Fed. Reg. 33,564 (June 18, 2007) (adopting implementing regulations and making them effective as of June 2007). Currently pending new CRARA rules, which were quickly proposed after the subprime meltdown, are admittedly more invasive. See supra note 4.

10. See, e.g., John Ammer \& Nathanael Clinton, The Impact of Credit Rating Changes on the Pricing of Asset-Backed Securities, in STRUCTURED CREDIT ProduCts: Pricing, Rating, Risk Management and Basel II 159 (William Perraudin ed., 2004); Frank Partnoy, The Paradox of Credit Ratings, in RATINGS, RATING AGENCIES AND THE GLOBAL FINANCIAL SYSTEM 65 (Richard M. Levich et al. eds., 2002) ; Konan Chan \& Narasimhan Jegadeesh, Market-Based Evaluation for Models to Predict Bond Ratings, 7 Rev. PAC. BASIN Fin. MARKeTS \& POLICIES 153 (2004); Claire A. Hill, Regulating the Rating Agencies, 82 WASH. U. L.Q. 43 (2004); Stéphane Rousseau, Enhancing the Accountability of Credit Rating Agencies: The Case for a Disclosure-Based Approach, 51 MCGILL L.J. 617 (2006); Steven L. Schwarcz, Private Ordering of Public Markets: The Rating Agency Paradox, 2002 U. ILL. L. Rev. 1; Patrick Bolton et al., The Credit Ratings Game (Nat'l Bureau Econ. Research, Working Paper No. 14712, 2009); Daniel M. Covitz \& Paul Harrison, Testing Conflicts of Interest at Bond Ratings Agencies with Market Anticipation: Evidence that Reputation Incentives Dominate (Fed. Reserve Bd., Working Paper, 2003); Jeffrey Manns, Rating Risk After the Subprime Mortgage Crisis: A User Fee Approach for Rating Agency Accountability, 8 N.C. L. REV. 1011 (2009); Joseph R. Mason \& Joshua Rosner, Where Did the Risk Go? How Misapplied Bond Ratings Cause Mortgage Backed Securities and Collateralized Debt Obligation Market Disruptions (Soc. Sci. Research Network, Working Paper No. 1027475, 2007), available at http://ssm.com/abstract=1027475; Vasiliki Skreta \& 
recommend fairly strong regulatory medicine. ${ }^{11}$ While this activity comes with a renewed vigor, it also comes against a long history of study concerning the $\mathrm{CROs}^{12}$ and financial-market gatekeepers more generally, ${ }^{13}$ much of which had already been fairly skeptical about those institutions. ${ }^{14}$ Nevertheless, as recently as late 2007 , influential observers still argued that CROs did not need oversight because they were already effectively regulated by market forces. ${ }^{15}$

Laura Veldkamp, Ratings Shopping and Asset Complexity: A Theory of Ratings Inflation (Nat'l Bureau Econ. Research, Working Paper, 2009), available at www.nber.org/papers/w14761; Lawrence J. White, Good Intentions Gone Awry: A Policy Analysis of the SEC's Regulation of the Bond Rating Industry (N.Y. Univ. Law \& Econs. Working Papers, Paper No. 69, 2006).

11. The best known suggestion is from Frank Partnoy's influential early article, which calls for removal of all regulatory reliance on the CROs' ratings, and instead recommends using market generated "credit spreads" as measures of risk. See Frank Partnoy, The Siskel and Ebert of Financial Markets?: Two Thumbs Down for the Credit Rating Agencies, 77 WASH. U. L.Q. 619, 704-07 (1999). Less-stark suggestions come in many varieties, usually calling for retention of the Nationally Recognized Statistical Rating Organization (NRSRO) designation, but with mandatory registration, some light oversight, and increased competition. See, e.g., Hill, supra note 10; Rousseau, supra note 10; Manns, supra note 10. One interesting suggestion from a truly impressive student is to retain NRSRO but empower the SEC to issue nonbinding "writ[s] of review" to call on the CROs to revise any rating thought to have become inaccurate. See Francis A. Bottini, Jr., Comment, An Examination of the Current Status of Rating Agencies and Proposals for Limited Oversight of Such Agencies, 30 SAN DiEGo L. REV. 579, 613 (1993).

12. Careful study of the CROs began as early as 1938. See GILbERT HAROLD, Bond RATINGS AS AN INVESTMENT GUIDE: AN APPRAISAL OF THEIR EFFECTIVENESS (1938), for an example of one such study. Many other studies have been conducted by lawyers and other market watchers and will be considered infra. Economists have studied the CROs' performance as an empirical matter since the late 1950s. See infra note 101 and accompanying text.

13. A foundational paper on the subject attempted to put some institutional flesh on the bones of the efficient capital market hypothesis. See generally Ronald J. Gilson \& Reinier H. Kraakman, The Mechanisms of Market Efficiency, 70 VA. L. REV. 549 (1984). As Gilson and Kraakman observed, it is one thing to assert and empirically prove that markets price efficiently, but another to explain how they manage it. See id. at 550-53 (explaining that, while the efficient capital market hypothesis was widely accepted, there was an absence of a unified explanation of market efficiency at that time). Since then, voluminous literature in economics and law has studied the question both theoretically and empirically.

14. See, e.g., John C. COFFEe, JR., GatekeePers: The Professions and Corporate Governance (2006); Stephen J. Choi \& Jill E. Fisch, How to Fix Wall Street: A Voucher Financing Proposal for Securities Intermediaries, 113 YALE L.J. 269 (2003); Jill E. Fisch \& Hillary A. Sale, The Securities Analyst as Agent: Rethinking the Regulation of Analysts, 88 IOWA L. REV. 1035 (2003) (challenging the notion of securities analysts as independent gatekeepers while evaluating analysts' behavior and impact on market efficiency); Frank Partnoy, Barbarians at the Gatekeepers?: A Proposal for a Modified Strict Liability Regime, 79 WASH. U. L.Q. 491 (2001).

15. See Posting of Joellen Perry to Real Time Economics, http://blogs.wsj.com/economics/2007/09/23/greenspan-slams-ratings-agencies (Sept. 23, 2007, 12:59 EST) (recounting media interviews with former Chairman Greenspan, in which he urged against regulation of CROs: "[CROs are] 'already regulated,' he says, because investors' loss of trust means the agencies are likely to lose business. 'There's no point regulating this. The horse is out of the barn, as we like to say."'); Schwarcz, supra note 10, 
The situation is not good. The debate has been, and should be, dominated by two policy concerns: whether private credit ratings improve capital-asset pricing efficiency, and whether they reduce systemic risk. At the moment, neither current events nor the extensive empirical literature on the CROs gives much reason for optimism as to either question. To whatever extent it may seem that private entities ordinarily need to not defend themselves on these grounds, the CROs must because they currently act as our main substitute for official supervision of significant aspects of financial markets.

However, the purpose of this Article is not to argue, as others have done and will do in the future, that the CROs have lacked oversight for too long or that their behavior has been suboptimal. This Article also does not urge any particular policy tweak to solve the industry's problems, although it is clear that a necessary (but not sufficient) step is removing regulatory reliance on the CROs. The Article will instead assert two more-general propositions. First, the industry in its current posture cannot be meaningfully regulated, despite the near-universal agreement that if it is to persist in its current quasi-governmental role, it must be regulated. Second, the industry's performance is likely to remain seriously disappointing under any conceivable change in policy or in an industry structure that still contemplates a major private role in formal assessment of credit risk. This will be shown in several ways. This Article will suggest reasons not to be too sanguine about any of the short-term regulatory solutions available at the moment, including legal and voluntary constraints currently in place and those that are currently pending before policymakers. The regulatory efforts that have recently been brought to bear on CROs are mainly structural tweaks and disclosure requirements meant to curtail conflicts of interest and increase CRO competition, which will not work. Controls were already in place to control conflicts and provide disclosure prior to the current economic catastrophe, and they have been shown to have been of no use. Likewise, while increased competition conceivably could improve the price competitiveness of ratings services, we will argue that it is unlikely to improve their quality. Indeed, all proposals so far suggested by academics and others, as well as a few developed in this Article, are fairly

at 15 (arguing that regulation of CROs is unnecessary because "the lack of official public scrutiny does not appear to affect ratings accuracy because of the de facto accountability of rating agencies through reputation"); see also Hill, supra note 10, at 44-45 (arguing that the need to protect "regulatory capital," the threat of potential competition, and the threat of potential regulation are all sufficient to ensure adequate $\mathrm{CRO}$ performance, and urging against new regulatory oversight); $i d$. at 44 ("While the regime could be improved, it is certainly not in dire need of repair. Rating agencies certainly didn't do a spectacular job with Enron, but there is considerable evidence that in the normal course, they do a good, if not stellar, job."). 
problematic, especially those that countenance some important continuing regulatory role for private, profit-making risk raters.

Ultimately, the CROs cannot be considered in isolation from the more fundamental problems of market intermediation, especially as it relates to financial innovation. On some level, debate about the CROs and how they should be regulated-and for that matter, debate about any informational intermediary-is somewhat superficial. The inherent problem of informational intermediation is basically one of industrial organization, and, as will be explained at length, it seems very thorny. No policy tool currently in force, and none of those with serious political feasibility, even comes close to dealing with it, and those more abstract proposals that might are both fairly politically implausible and raise serious problems of cost and uncertainty. The problem is not the CROs themselves nor the details of any regulatory policy set up to constrain their abuses, but rather the problem is a combination of factors inherent in the market for privately organized production of financial market information. Critically, we will stress that informational problems in financial markets would not simply resolve themselves if the government stopped relying on CRO ratings in its regulation of those markets. In short, the purpose of this Article is to argue that capital markets currently contain a much more serious institutional flaw than has been recognized.

\section{THE RISE OF THE CROS}

\section{A. How the CROs Came to Be}

Careful histories of the CROs exist, so this Article sets out only relevant background. ${ }^{16}$ Coming up with credit ratings ${ }^{17}$ is an old business, finding

16. Among the best histories of the agencies are Frank Partnoy's influential article, The Siskel and Ebert of Fiancial Markets?: Two Thumbs Down for the Credit Rating Agencies, 77 WASH. U. L.Q. 619, 636-54 (1999), and Richard Sylla, An Historical Primer on the Business of Credit Rating, in Ratings, Rating AgENCIES AND THE Global FinANCIAL SYSTEM 19 (Richard M. Levich et al. eds., 2002), and, as to the industry's early history, a book on which other histories rely heavily, HAROLD, supra note 12. Also very good are COFFEE, supra note 14, at 283-314, SINCLAIR, supra note 5, at 22-49, and Richard Cantor \& Frank Packer, The Credit Rating Industry, FED. RES. BANK OF N.Y. Q. REV., Summer-Fall 1994, at 1.

17. A "credit rating" is an assessment of the likelihood that the issuer of a fixed income security will meet its obligations according to the terms of the security and in a timely manner. See Standard \& Poor's, About Credit Ratings, http://www2.standardandpoors.com/aboutcreditratings (last visited June 14, 2009). CROs do not typically rate equity securities. The CROs predominantly rate (1) the general creditworthiness of particular issuers, and (2) publicly traded debt securities, preferred shares, and privately placed securities issued by structured finance issuers. 
antecedents in the United States in the mid-nineteenth century. ${ }^{18}$ It has remained a predominantly American phenomenon, not only because of the American ratings firms' size and competitive advantages, but because until recently, U.S. capital markets were quite different than those overseas. ${ }^{19}$ In any case, the two dominant U.S. CROs, Moody's Investors Services (Moody's) $^{20}$ and Standard \& Poor's Ratings Services (S\&P), ${ }^{21}$ currently face meaningful competition only from a third and much smaller U.S.based firm, Fitch Ratings (Fitch). ${ }^{22}$ The number of large, general-purpose

18. "Mercantile" credit rating agencies reported on merchant creditworthiness as early as the 1840 s. Several of them later combined to form what is now Dun \& Bradstreet. Other forms of widely disseminated, financial-data publications began at about the same time. See Partnoy, supra note 11, at 636-37. But, as Sinclair observes, the CROs began to take their modern form only in 1909, when John Moody first began issuing ratings that actually made judgments about creditworthiness. Sinclair says the transition to this process of informed appraisal was a response to the financial panic of 1907. Overall, Sinclair describes this period-from the mid-nineteenth century to about World War I-as an "information explosion" in American finance. See SinClAIR, supra note 5, at 23-24. Moody claimed to have taken his model from a predecessor in Austria, but no trace of it has been found. Id. at $24 \mathrm{n} .11$. Thus, the business of systematic risk assessment of debt securities appears to have an American origin.

19. In fact, for the most part, borrowing from capital markets rather than banks was itself essentially an American practice until the 1960s. Though government-issuer bond markets have existed since the early seventeenth century, corporate bond markets only emerged around 1850 in the United States, with the need to finance the expanding railroads. See Sylla, supra note 16, at 22-24. White speculates that the dominance of bank lending in most other places may reflect their smaller geographic size, allowing for better borrower oversight through branching. See White, supra note 5 , at 58 n. 21 .

20. Moody's currently exists as a publicly traded holding company, Moody's Corporation, which provides credit rating services through its subsidiary Moody's Investors Service. A separate subsidiary, Moody's Analytics, sells various nonratings services. John Moody was not the first to publish reports on corporate creditworthiness, nor was he even the first to systematize bond ratings into simple symbols, but he was the first to establish it as a going business. Interestingly, he also aspired to muckraking journalism and public service generally, and wrote a treatise on abuse and power on Wall Street that is still read today. See SINCLAIR, supra note 5, at 6 (discussing John Moody, The Masters of Capital: $A$ Chronicle of Wall Street, in 22 GREAT LEADERS in Business AND POLITICS: THE CHRONICles OF AMERICA SERIES 1 (Allen Johnson ed., 1919)); SINCLAIR, supra note 5, at 23-24 (laying out early history of the Moody's enterprise). John Moody's original business was acquired by Dun \& Bradstreet in 1962 and was spun off in late 2000. It has remained a freestanding publicly traded corporation ever since. See Moody's Corp., Annual Report (Form 10-K), at 1-2 (Feb. 29, 2008), http://sec.edgar-online.com/moodys-corp-de/10-k-annualreport/2008/02/29/Sectionl.aspx [hereinafter 2007 Annual Report Form 10-K].

21. S\&P arose from the 1941 merger of the Standard Statistics Bureau and Poor's Publishing, but both companies had been in the business of securities analysis long before that. Poor's published financial data since Henry Varnum Poor's 1860 publication of History of Railroads and Canals in the United States. S\&P's debt-rating business began in 1916 when Standard began publishing them. S\&P has been a subsidiary of the McGrawHill publishing enterprise since 1966. See Standard \& Poor's, Company History, http://www2.standardandpoors.com (follow "Company History" hyperlink in "About S\&P" drop-down menu) (last visited July 28, 2009).

22. Since 1997 Fitch has been wholly owned by a French holding company, Fimilac, S.A. Until 2006, Fimilac had been diversified in a range of manufacturing businesses but 
ratings firms has mainly fluctuated between three and five throughout the industry's entire history, ${ }^{23}$ though many smaller CROs exist around the world. ${ }^{24}$

The history of the CROs cannot be understood apart from their relation to various governments. Since 1936 the U.S. government has imposed requirements on financial institutions and investment managers that prospectively incorporated CRO ratings into investment rules. Similar state requirements quickly followed. ${ }^{25}$ While this regulatory partnership plainly aided the CROs financially, the number and effect of the regulatory incorporations blossomed in the early 1970s with the Securities and Exchange Commission's (SEC's) decision to make special regulatory use of ratings in setting capital requirements for securities firms. Thus arose the SEC's now-familiar "Nationally Recognized Statistical Rating Organization" (NRSRO) designation. ${ }^{26}$ Since then scores of federal and

has now divested all but Fitch and a related firm, the Toronto-based risk-management outfit Algorithmics. The History of Fitch Ratings, $\mathrm{http}: / / \mathrm{www}$.fitchratings.com/jsp/corporate/AboutFitch.faces?context=1\&detail=3 (last visited July 28,2009 ) (providing a brief history of the foundation and reorganization of Fitch). Fitch's predecessor was founded as an independent publishing firm in New York in 1913 and issued its first bond ratings in 1924. See Partnoy, supra note 11, at 639 (recalling Fitch's entry into the bond rating market)

23. See White, supra note 10 , at 1-2 (discussing the historical dominance of a select group of rating firms). At times some other nontrivial competitors have flourished, and there remain a few firms with significant roles in niche ratings specialties. $I d$. at 2. Specifically, A.M. Best Company persists as a rater of insurance companies and was given limited NRSRO designation in 2005 to rate their likelihood of paying claims. See A.M. Best Co., Inc., SEC No-Action Letter, 2005 WL 678,901 (Mar. 3, 2005), available at http://www.sec.gov/divisions/marketreg/mr-noaction/am030305.htm. (granting tentative, limited authority). Prior to their acquisition by Fitch in 2000, the English firm IBCA and the Canadian firm Thomson BankWatch had enjoyed a long history as raters of banks and financial institutions. See The History of Fitch Ratings, $\mathrm{http} / / \mathrm{www}$.fitchratings.com/jsp/corporate/AboutFitch.faces?context=1\&detail=3 (last visited July 28, 2009) (commenting on the postmerger proliferation of Fitch Ratings).

24. As of September 1999, the Bank for International Settlements identified as many as 130 CROs worldwide. See Arturo Estrella et al., Credit Ratings and Complementary Sources of Credit Quality Information 14 (Basel Comm. on Banking Supervision, Working Paper No. 3, 2000), available at http://www.bis.org/publ/bcbs_wp3.pdf (conservatively estimating the total number of rating agencies, but indicating that that number could be as high as 150).

25. Beginning in 1931 with an explicit capital requirement for federal banks imposed by the Comptroller of the Currency, the federal government began "incorporating credit ratings into substantive regulations." See Partnoy, supra note 10, at 70 (arguing that implementation of credit ratings as a means for determining the caliber of bank holdings created a high-demand market for ratings agencies).

Since the mid-twentieth century state regulators of banking and insurance have used bond ratings in capital adequacy regulation. See THOMAS R. ATKINSON, TRENDS IN CORPORATE BOND QUALITY 52-53 (1967) (noting the 1949 adoption by National Association of Supervisors of State Banks and the 1951 adoption by National Association of Insurance Commissioners).

26. This designation has been one significant barrier preventing competitive entry into 
state laws have come to incorporate NRSRO ratings, ${ }^{27}$ and CROs have also been given other regulatory advantages. ${ }^{28}$ Similar use of ratings has been made by courts, ${ }^{29}$ investment-fund designers, ${ }^{30}$ other private parties, ${ }^{31}$ and increasingly by foreign governments. ${ }^{32}$

The history likewise cannot be understood without some attention to the revolution that appears to have surrounded an unexpected liquidity crisis in

the CRO market (and we will make the case that there have been others). In 1973, the SEC adopted a rule requiring that certain regulated securities firms' minimum capital reserves be calculated by using different "haircuts" for securities with specific NRSRO ratings. See SEC, supra note 3 , at 6 . As White observes, U.S. regulators had long incorporated ratings in various ways, but prior to 1975 , regulators generally referred only to "recognized ratings manuals." It was only in the SEC's regulation of 1975 that specific firms were identified whose ratings must be used. See White, supra note 10, at 3-6 (inferring that the pre-1975 language was nonetheless "probably understood to mean Moody's, S\&P, and Fitch"). The SEC's move may have reflected the CROs' then-recent switch to the "issuer-pays" business model. But see id. at 3-4 (offering an opposing rationale for the switch). Given that model, the use of ratings in regulation would create a greater risk of unscrupulous raters selling investment-grade ratings to any issuer willing to pay. See id. at 6-7 (noting that because the new SEC rule essentially guaranteed demand for ratings, the newly designated NRSRO had little motivation to improve the quality of their product). See generally Partnoy, supra note 11 , at 690-91 (citing 17 C.F.R. $§ 240.15 c 3-1$ (1998) (discussing the promulgation of SEC Rule 15c3-1 and the "cascade of regulation" that followed)).

27. As of 2002, the NRSRO concept was explicitly incorporated in eight federal statutes and sixty federal regulations, mostly in banking and securities regulation. See Partnoy, supra note 11, at 74-75. Partnoy also notes that, if anything, CROs enjoy even more influence through the informal use that state and federal regulators make of the NRSRO concept in the many orders, releases, and letters of their day-to-day business. Id. at 75.

28. Notably, the CROs are explicitly exempted from the Regulation Fair Disclosure (FD) ban on selective disclosure of material nonpublic information, and are sometimes privy to such information when making their ratings. See Regulation FD, 17 C.F.R. $\$ 243.100(b)(2)($ iii) (2008) (making disclosure requirements inapplicable "[t]o an entity whose primary business is the issuance of credit ratings"). While material nonpublic information could theoretically increase the accuracy of ratings, the CROs claim they can produce accurate ratings without this special dispensation.

29. Since the early twentieth century, courts considering fiduciary litigation against trustees and other investment managers found investment in highly rated instruments to weigh in favor of the fiduciary. See Partnoy, supra note 11, at 640-41 (providing a brief survey of cases from the 1920 s and 1930 s that utilized ratings to determine liability).

30. Since at least the early $1930 \mathrm{~s}$, many trusts and other institutional investors have explicitly limited their managers' investments by reference to CROs' ratings. See id. at 644 (discussing early use of ratings to craft principles).

31. Explicit references to CROs' ratings, often using the NRSRO designation, have been included in an unknown but unquestionably massive number of private contracts and financial instruments. Typically those terms provide that in the event of an NRSRO downgrade of a party to the transaction or some instrument that underlies it, certain consequences follow, such as constructive default or accelerated repayment. See Partnoy, supra note 11, at 676-81 (explaining the operation of CRO ratings in the credit derivatives market).

32. The CROs enjoy some overseas regulatory benefits with the incorporation of U.S. NRSRO ratings in the laws of other countries, and with the gradual implementation of the Basel II External Credit Assessment Institution initiative. See supra note 5 (summarizing the impact of foreign regulations on CROs). 
$1970{ }^{33}$ prior to which U.S. corporate debt markets had performed well. ${ }^{34}$ The calamity of 1970 happened to roughly coincide with certain worldwide monetary changes. ${ }^{35}$ The major consequence for the CROs would turn out to be a very profitable change in their business model. Apparently to take advantage of a substantial increase in demand for analytical risk intermediation, the major CROs each, within the space of a few years, switched from selling subscriptions to the so-called issuer-pays model: when one of the major CROs rates an issuer or its debt securities, the issuer almost always pays for the rating that is issued. ${ }^{36}$

By all accounts, the worldwide CRO industry is a massive duopoly, ${ }^{37}$ and given the so-called two-ratings norm-most issuers seek the ratings of both Moody's and S\&P, even though they are not required to do so-- ${ }^{38}$

33. In a well-known story, the Penn Central Railroad unexpectedly defaulted on $\$ 82$ million in commercial paper in 1970, which was followed by other short-term defaults and a general short-term liquidity crisis. See White, supra note 5, at 47 (characterizing the defaults as "a defining moment that has focused both issuers and investors on the risks of such issuances").

34. In what remains the most comprehensive study of U.S. corporate bond performance, National Bureau of Economic Research (NBER) economist Braddock Hickman found that during the first half of the twentieth century investors in U.S. bonds enjoyed a net loss rate of almost exactly zero-a result Hickman called "a tribute to the ability of domestic business corporations to service their long-term obligations . . ." W. BRADDOCK HICKMAN, CORPORATE BOND QUALITY AND INVESTOR EXPERIENCE 7-8 (1958) [hereinafter HICKMAN, INVESTOR EXPERIENCE]. By "zero net loss," Hickman meant that the overall capital gains earned by increasing bond prices in secondary trading almost exactly set off losses from defaults. Id. Sylla expresses some doubts as to Hickman's optimism. As he observes, on the basis of his own work, U.S. interest rates began at an already low rate in 1900 and gradually declined throughout the period of Hickman's data to near all-time lows around the end of World War II. He says that this "trend may account for a good part of the capital gains on bonds that offset losses from defaults." Sylla, supra note 16, at 26.

Hickman's work appeared in three separate volumes. W. BRADDOCK HICKMAN, Statistical MEASURES OF CORPORATE BONd FinANCING SINCE 1900 (1960); W. BRADDOCK HICKMAN, CORPORATE BOND QUALITY AND INVESTOR EXPERIENCE (1958); W. BRADDOCK HICKMAN, THE VOLUME OF CORPORATE BOND FINANCING SINCE 1900 (1953).

35. As will be discussed, the late 1960s and early 1970s saw a significant increase in exchange and interest-rate volatility associated with the breakdown of the Bretton Woods monetary system. Certain new trends arose in innovative, experimental financial products that were meant to help firms smooth their risks in part to address that new volatility. See infra notes 74-75 and accompanying text (discussing the development of the novel practices).

36. White argues, by contrast, that this transition merely reflected the rise of low-cost photocopying, which posed a free-rider problem for the rating firms, which they attempted to avert by switching to the issuer-pays model. See White, supra note 10, at 3-4.

37. As of 2006 , Moody's and S\&P had $80 \%$ of the market as measured by revenue, but they rated as much as $99 \%$ of publicly traded debt issues and preferred stock in the United States. See S. REP. No. 109-326, at 4 (2006), reprinted in 2006 U.S.C.C.A.N. 865. In fact, an early version of CRARA was titled the "Credit Rating Agency Duopoly Relief Act of 2005." H.R. 2990, 109th Cong. (2005).

38. Issuers obtain both ratings in part because some of the regulatory and privatecontract provisions requiring investment in rated securities require that an issue receive a minimum rating from two NRSROs. However, even though most regulatory rating 
some observers characterize them as a "partner monopoly." 39 They also retain unrivaled dominance overseas. ${ }^{40}$ While several new foreign agencies have risen, they frequently have operating partnership arrangements with the U.S. firms or are owned by them. Such independent agencies mostly remain small, and in some cases there is reason to doubt their independence and veracity. Again, as it does here in the United States, Fitch holds a fairly distant third-place position overseas. The dominance of the major CROs likely has more than one cause. It is frequently explained by the NRSRO designation and the need of most institutional investors for NRSRO-rated securities. But it seems likely that even if NRSRO rules were to be repealed, entry now would be severely impeded by the need to establish reputation as a seasoned CRO. ${ }^{41}$ The privilege of duopoly has been very profitable. ${ }^{42}$

requirements do not call for more than one rating, the vast majority of issuers voluntarily acquire ratings from both Moody's and S\&P anyway. See Richard Cantor \& Frank Packer, Multiple Ratings and Credit Standards: Differences of Opinion in the Credit Rating Industry, FED. RES. BANK OF N.Y. STAFF REP., Apr. 1996, at 3-6, available at $\mathrm{http}: / /$ www.newyorkfed.org/research/staff_reports/sr12.pdf (explaining the prevalence of issuers acquiring both Moody's and S\&P ratings).

39. One important entity that characterized the situation as a partner monopoly is the Antitrust Division of the U.S. Department of Justice. See Jonathan R. Laing, Failing Grade, BARRON's, Dec. 24, 2007, at 19, 20 (alluding to the designation of "partner monopoly" used by unnamed Justice Department staffers).

40. Moody's and S\&P both cover European bond ratings extensively, and have extensive coverage in Latin America and Asia, although S\&P is more dominant in the former and Moody's is more dominant in the latter. White, supra note 5, at 44-45.

41. Partnoy observes that entry costs appear to have been quite low in the industry's early years, as the process of analyzing even a large amount of publicly available financial data should not, in principle, entail extraordinary costs or sunk investment, or pose regulatory hurdles. See Partnoy, supra note 11, at 636-40 (asserting that low overhead costs and ease of entry allowed agencies the ability to quickly gain-or lose-"reputational capital"). Times now seem significantly different.

42. In 2006 Moody's earned $\$ 1.1$ billion on only $\$ 2$ billion in revenue, and until recently, Moody's operating margins ran typically to more than $50 \%$ per year. Laing, supra note 39 , at 20. Evidence for prior years is comparable. See White, supra note 5, at 49 (reporting that for the years 1995 to 2000 Moody's average after-tax net income was $42 \%$ ). Though S\&P's performance results are not as publicly available, it stands to reason that its performance has been similar. The two firms have long enjoyed comparable market shares and have near-identical pricing structures. These results are often taken to reflect the privilege of NRSRO status, as their performance and pricing structure are hard to explain without some strong assumption of market power associated with regulatory rules. As White observes, Moody's and S\&P impose almost identical, flat-fee structures that are keyed to the size of the issues under review. Both firms offer discounts for repeat business, though the details of those discounts have not been made public. See id. at 47-48 (asserting that although Moody's and S\&P automatically rate "all[] SEC-registered corporate bonds," an overwhelming majority of issuers pay for the service, allowing the agencies to set lower fees). He argues at length that their fee structure is best explained as the result of a substantial amount of market power, unconstrained by even potential entry.

White points out a certain mystery surrounding the CROs' pricing and coverage behavior. Given the apparently rigid two-ratings norm, each major may have fairly little to fear from unilateral price increases. See supra notes $37-38,41$ and accompanying text 
There is reason to expect that Moody's and S\&P could still command substantial market share even without the NRSRO designation because of the two-ratings norm, and because of the periods prior to the dominance of NRSRO in which ratings from the majors severely constrained access to debt markets. ${ }^{43}$ These facts are theoretically somewhat difficult to explain. Many have claimed that some part of the explanation is due to the substantive value issuers find in ratings, ${ }^{44}$ though that in itself seems unlikely to explain their massive, sustained profits.

The CROs earn their revenues overwhelmingly from issuer-pays ratings fees. ${ }^{45}$ CRO reform proposals sometimes suggest abolishing the issuerpays model and frequently call for repeal of the NRSRO concept, which might drastically reduce demand for issuer-paid ratings. The CROs probably could not persist at their current scale of operations without the issuer-pays model, and may not survive its loss. Securities research is difficult to support on subscription fees alone, which is shown by the decline in the equity-securities analysis field since its major scandal a few years ago, ${ }^{46}$ by the financial difficulties suffered by the CROs themselves

(discussing the causes and likely continuation of Moody's and S\&P dominance). On these facts they ought to be able jointly to raise profits by reducing output. White considers this a "puzzle to which we can only supply some partially satisfactory answers." See White, supra note 5 , at 48 (addressing, but ultimately not adopting, four possible explanations for the status quo of the firms' pricing parity).

43. A credit crunch in 1974 and 1975 foreclosed many issuers from bond markets entirely if they could not secure high investment-grade ratings. The crunch seems to have reflected the liquidity tightening following the Penn Central default in 1970 and the generally difficult circumstances of the early 1970s. See Marilyn Much, The Rating Game: When Baa Spells Bah, INDUSTRY WK., Jan. 8, 1979, at 44 (describing the condition of the credit markets in the 1970s).

44. See, e.g., Hill, supra note 10, at 64-90 (arguing that the two-ratings norm is perpetuated not by issuers seeking "favorable regulatory treatment," but by the informational value provided by the ratings of Moody's and S\&P).

45. While most CROs sell products other than the ratings they provide (e.g., most produce various periodicals, sell subscriptions, consulting services, nonratings analytical software, and the like), the CROs earn almost all of their revenues from ratings fees charged to the rated issuers. Partnoy, supra note 11 , at $652 \mathrm{n} .162$ and accompanying text.

46. At one time, most major investment banks and brokerages employed in-house securities analysts, as they found them to be profitable adjuncts to their other businesses. The analysts were heavily subsidized by those other business units-as was necessarily the case because their analysis was distributed free to firm clients-but when legal intervention by the SEC and the New York Attorney General famously forced the banks to disentangle and isolate their analysts from conflicts of interest, those departments quickly shriveled. The business of securities analysis is now a shadow of what it was during that period, such that proposals are now being made to prop it up with subsidies of various kinds. See COFFEE, supra note 14, at 245-73 (discussing the rise of firm use of in-house analysts and the likely causes of its decline); Choi \& Fisch, supra note 14, at 312 (noting the downturn in the number of analysts employed by financial firms during the early $2000 \mathrm{~s}$ ); John L. Orcutt, Investor Skepticism v. Investor Confidence: Why the New Research Analyst Reforms Will Harm Investors, 81 DENV. U. L. REV. 1, 26-77 (2003) (recounting at length regulatory intervention in the industry and its drawbacks, and suggesting an SEC "warning label" on 
during the 1940s, 1950s, and 1960s, before the adoption of issuer-pays, ${ }^{47}$ and by the fact that only relatively small CROs currently operate on subscription fees. This is probably because securities research is expensive, ${ }^{48}$ and because on even a semi-strong efficient-markets assumption, it should be difficult to extract sufficient subscription revenues. $^{49}$

Finally, the CROs have been the focus of unceasing criticism that seriously calls into question policymakers' reliance upon credit ratings. There have been two central themes: (1) doubt that ratings add new information sufficient to justify their cost, and (2) alarm over their failure to predict financial distress involving companies that they rate. We will explore the former in detail later, ${ }^{50}$ though it is worth noting that as far back as 1938 , observers questioned the value of ratings. ${ }^{51}$ As to the latter, catastrophic failures of CRO predictions go back thirty years or so and include several types of debt, beginning with the failure to predict the massive bond defaults by New York City in 1975 and the default by the Washington Public Power Supply System in 1983..$^{52}$ They also failed to predict several massive derivatives-related losses, which literally spanned the $1990 \mathrm{~s},{ }^{53}$ the Asian currency crisis that followed a few years later, ${ }^{54}$ and

securities analysis as an alternative).

47. See Partnoy, supra note 11 , at $646-47$ (recounting the effect of a relatively stable bond market on the demand for ratings); Richard House, Ratings Trouble, InstituTional INVESTOR, Oct. 1995, at 245 (commenting that the adoption of issuer-pays has caused a "major schism in the industry").

48. See Orcutt, supra note 46, at 16 \& nn.70-71 (citing Kent L. Womack, Do Brokerage Analysts' Recommendations Have Investment Value?, 51 J. FIN. 137, 138 (1996)) (noting the substantial costs to investment banks).

49. Assuming, as the semi-strong position does, that securities prices reflect all publicly available information, then as soon as a CRO distributes analysis to a few subscribers, the information should be reflected in bond and stock markets. See Eugene F. Fama, Efficient Capital Markets: A Review of Theory and Empirical Work, 25 J. FIN. 383, 404-09 (1970) (evaluating studies on stock splits and earnings reports to explain the semistrong form theory underlying the efficient-markets hypothesis and ultimately concluding that the theory has the highest potential for future empirical use). Therefore most investors will not have much incentive to pay CRO subscription fees-any gains to be made on the basis of CRO recommendations should be captured too quickly for most investors to exploit.

50. See infra Part III (addressing the missing theoretical basis for both CROs and the potential for added value in ratings).

51. See generally HAROLD, supra note 12 (examining the already widespread and vital role bond ratings played in investment decisionmaking during the early twentieth century).

52. See Bottini, supra note 11, at 584-87 (summarizing the criticisms of Moody's and S\&P's perceived slow responses to the numerous red flags preceding the two major bond defaults).

53. The highest profile losses of this period were (1) Gibson Greetings, Inc.'s $\$ 16.7$ million loss and Proctor \& Gamble's $\$ 157$ million loss, both involving complex interest-rate derivatives traded with Bankers Trust; (2) the $\$ 2.5$ billion loss suffered by Orange County, California on several complex derivatives arrangements with Merrill Lynch and other banks; and (3) the $\$ 1.5$ billion loss suffered by Barings Bank as a result of the trading 
the corporate collapses of the early twenty-first century. ${ }^{55}$ Their role in the current credit crisis is better characterized as active complicity, as they helped create the market for subprime residential mortgage-backed securities (RMBS) and related derivative products. ${ }^{56}$ This did not stop until these markets collapsed all at once, on the day when Moody's and S\&P simultaneously downgraded large numbers of subprime structured bonds, the day now known as "Pearl Harbor Day.","7

\section{B. How They Do What They Do}

The standard rating process has been recounted extensively elsewhere, ${ }^{58}$

activity of a twenty-seven-year-old trader named Nick Leeson. See generally FRANK PARTNOY, INFECTIOUS GREed: How DECEIT AND RISK CORRUPTED THE FINANCIAL MARKETS 49-53, 112-115 (2003) (providing an in-depth explanation of Gibson Greetings' losses); SINCLAIR, supra note 5, at 157-60 (recalling the failed investment portfolio of Orange County Treasurer Robert L. Citron and the unsuccessful lawsuit the County brought against S\&P); Lynn A. Stout, Betting the Bank: How Derivatives Trading Under Conditions of Uncertainty Can Increase Risks and Erode Returns in Financial Markets, 21 J. CoRP. L. 53, 53-54 (1995) (discussing the substantial losses sustained by Proctor \& Gamble and Barings).

54. This crisis has been attributed in large part to derivative instruments that attempted arbitrage against the currency of Thailand, which for some years had been arbitrarily maintained by that country's central bank. See SinclaIR, supra note 5, at 160-67 (detailing the two stages of the 1997 Asian financial crisis and the wave of criticism directed at the major rating agencies).

55. See id. at 167-72 (discussing the 2001 Enron bankruptcy, ensuing legislation, and inquiries into additional SEC oversight of NRSROs).

56. Structured securities are deliberately designed so that some portion of the securities issued by any structured entity will enjoy the highest or a very high investment-grade rating. This fact drove the intense demand of institutional investors for structured securities with the riskiest underlying collateral because top-tranche bonds pay regularly and typically at a rate higher than other similarly rated bonds. Further, they satisfy the requirement of many institutional investors to purchase mainly investment-grade instruments. CROs helped securitizers to prearrange securitizations by selling consulting services to ensure highest possible ratings for top-tranche securities, and even helped repackage parts of the lowest rated tranches into new securitizations, turning a significant portion of them into highly rated derivatives. See generally Kenneth C. Kettering, Securitization and Its Discontents: The Dynamics of Financial Product Development, 29 CARDOzO L. REV. 1553 (2008) (critiquing the legal bases of securitization and providing a comprehensive study of its prevalence). Structured finance ratings were by far the CROs most profitable business for many years. See infra note 108 (noting the 2002-2006 revenue). They were also the most plagued with conflicts of interest, and they bore a frightening resemblance to those in the accounting industry prior to its collapse, when firms like Arthur Andersen were selling management consulting services to firms they audited.

57. On that day, July 10, 2007, Moody's and S\&P simultaneously announced credit downgrades as to $\$ 20$ billion worth of subprime mortgage-backed bonds. See Laing, supra, note 39 , at 19 (describing the onset of a series of downgrades). No less than a month later, SEC staff launched a formal investigation pursuant to statutory authority, and it is perhaps a sign of changing times that the three major CROs complied so fully in the investigation, producing millions of pages of internal documents, communications, and e-mails. See generally SEC 2008 STAFF REPORT, supra note 3.

58. See, e.g., YARON ERnst, MoOdy's InVestors Serv., The COMBINEd Use of 
and an outline of the process has been disclosed by the CROs in publicly accessible documents. ${ }^{59}$ In the broadest terms, it resembles the judgments lenders ordinarily make about the creditworthiness of their counterparties, ${ }^{60}$ though in many cases CRO procedures contain internal controls and appeal opportunities for issuers. ${ }^{61}$ Accordingly, if the CROs really do possess some genuine comparative advantage, it is likely not in the substance of their rating methodologies. Theoretical approaches to credit risk assessment are extensively studied by academics and other professionals, ${ }^{62}$ and a substantial body of empirical evidence shows that credit ratings can largely be predicted on the basis of simple financial ratios generated from

Qualitative Analysis and Statistical Models in the Rating OF Securitisations 6-8 (2001), available at http://www.moodys.com/moodys/cust/research/ MDCdocs/20/2001200000348392.pdf (providing an overview of the qualitative and quantitative analyses employed by Moody's); BIS STRUCTURED FINANCE REPORT, supra note 5, at 14-16 (contrasting components of the rating process for bonds with that of structured finance products); SEC 2008 STAFF REPORT, supra note 3, at 7-10; Partnoy, supra note 11, at 651-52; Hearing on Credit Rating Agencies Before the H. Comm. on Oversight and Government Reform, 110th Cong. 5-8 (2008) (testimony of Raymond W. McDaniel, Chairman \& Chief Executive Officer, Moody's Corporation) [hereinafter McDaniel Testimony] (outlining Moody's credit rating process).

59. See, e.g., MOODY'S InVESTORS SERV., Understanding MOODY's CoRPORATE BOND RATINGS AND RATING PROCESS (2002), available at http://v2.moodys.com/moodys/cust/research/MDCdocs/06/2001400000389218.pdf; JAY SIEGEL, MOOdY's INVESTORS SERV., MOODY'S MoRTGAGE METRICS: A MODEL ANALYSIS OF RESIDENTIAL MORTGAGE POOLS (2003), available at http://v2.moodys.com/cust/content/Content.ashx?source=StaticContent/Free\%20Pages $/$ Prod ucts\%20and\%20Services/Downloadable\%20Files/m3\%20special\%20report.pdf; STANDARD \& POOR's FIN. SERVS., GUIDE TO CREDIT RATING ESSENTIALS (2009), available at http://www2.standardandpoors.com/spf/pdf/fixedincome/SP_CreditRatingsGuide.pdf.

The precise process each CRO uses is proprietary and its details are typically kept secret. See SinclaIR, supra note 5, at 33-34 (stating that not only are the criteria important to the CRO, but also that publishing criteria would distort expectation among issuers); Partnoy, supra note 10 , at 73 (noting the unexpected nature of the CROs' secretive and qualitative process).

60. See Partnoy, supra note 11 , at 651 (noting that "the process agencies use today to generate ratings does not provide any obvious advantages over those used by competing information providers and analysts").

61. Initially, a lead analyst assigned to the given issue or issuer undertakes both a quantitative and qualitative analysis of the default risk posed, including, as a major component, quantitative credit-risk modeling. The analyst then presents a proposed rating for a vote to a "ratings committee," which is composed of other analytical staff. After the committee has decided on a rating, the issuer can review it before the rating is published. If the issuer feels the rating is based on incorrect information, the issuer may disagree with the rating and appeal to the committee to change it. This appeal will not necessarily be granted. Some CROs allow issuers to veto the release of the rating. See Who Rates the Raters?, ECONOMIST, Mar. 26, 2005, at 68. Once a final rating has been settled on, it is published and subsequently monitored. See generally McDaniel Testimony, supra note 58, at 5-8; SEC 2008 STAFF REPORT, supra note 3 , at 9.

62. See Til Schuermann, A Review of Recent Books on Credit Risk, 20 J. APPLIED ECONOMETRICS 123 (2005) (surveying literature discussing the diverse set of issues surrounding credit risk). 
publicly available data. ${ }^{63}$ In any case, ratings fees are typically negotiated up front and include break-up fees should the issuer ultimately choose not to have the rating issued by that particular CRO. ${ }^{64}$

The process for rating structured products, such as mortgage-backed securities (MBSs), is somewhat more involved, and has posed special problems. $^{65}$ Issuers approach CROs with pools of asset-backed securities (ABSs) to be rated, typically having prestructured them using software that the CROs themselves create and sell to ensure a desired rating for the highest tranches in the pool. ${ }^{66}$ The arranger then indicates its desired target rating and discusses with the CRO how the pool's structure may be adjusted to achieve that rating. ${ }^{67}$ Quantitative factors considered include the degree of credit enhancements in the pool ${ }^{68}$ and the historical performance of similar assets created by the originators. ${ }^{69}$ The qualitative

63. See infra note 102 and accompanying text.

64. BIS STRUCTURED FINANCE REPORT, supra note 5, at 14; SEC 2008 STAFF REPORT, supra note 3 , at 9 (stating that rating agencies may not receive payment if no rating is eventually published).

65. Rating other structured products, such as collateralized debt obligations (CDOs), is similar. When CDOs are rated the only assets investigated are the MBS and not their underlying asset pools. Because CDOs are actively managed, their composition changes over time. Thus, CDO ratings are not based on pool composition, but rather on the covenanted limits for each asset the CDO can hold. SEC 2008 STAFF REPORT, supra note 3, at 9. One of the puzzling aspects of CDO ratings is how analysts believed they could provide accurate ratings without investigating the assets underlying the ABS in the CDO. Indeed, some smaller CROs refused to rate CDOs because their composition made little sense.

66. See McDaniel Testimony, supra note 58, at 12 (explaining Moody's role in the mortgage securitization process); SEC 2008 STAFF REPORT, supra note 3, at 8 (examining the steps analysts take when rating securitized mortgages).

Thus, for example, if the preliminary rating is based on the pool's structure, the arranger may restructure the pool to ensure the highest possible rating. The majority of adjustments that have to be made to the pool to achieve an investment-grade rating, however, take place in the initial back-and-forth between the CRO and the issuer or via use of CRO software. BIS STRUCTURED FinANCE REPORT, supra note 5, at 26.

67. BIS STRUCTURED FINANCE REPORT, supra note 5, at 26. Importantly, the conflicts of interest that arise when a CRO sells advice on structuring a product to improve its rating and then rates that same product are almost identical to the conflicts of interest that plagued accounting firms at the turn of the century. In fact, the conflicts inherent in accounting firms selling management consulting services to a corporation and then auditing that same corporation are often cited as a root cause of the failure of the largest accounting firms and their largest clients. The primary difference between the two is that the CROs have not failed due to their behavior, even though their structured finance ratings did.

68. Credit enhancements may take a number of forms. For example, they could include an originator guaranteeing portions of losses in certain tranches or insurance companies insuring against some losses.

69. McDaniel Testimony, supra note 58, at 6. One wonders how this was possible with some new and innovative assets, such as pay-option adjustable-rate mortgages, securitizations of which grew from $\$ 1.8$ billion in 2002 to $\$ 154$ billion in 2005 . AMITA SHRIVASTAVA \& TODD SWANSON, MOODY'S INVESTORS SERV., RATING U.S. OPTION ARM RMBS-MOODY'S UPDATED RATING APPROACH 2, fig. 1 (2007), available at http://www.moodys.com/moodys/cust/research/MDCdocs/04/2006800000450911.pdf. 
factors considered also differ in the structured context and have caused concern. $^{70}$

\section{THE ENTANGLED GROWTH OF INNOVATION, DISINTERMEDIATION, AND DEREGULATION}

The fate of the CROs, in some part by their own doing, has been bound up with two significant developments in recent history: (1) the evolution of new financial products, a process commonly called financial innovation, and (2) the process of disintermediation, which is the gradual transition from indirect investment through bank deposits to direct investment in securities, with a resulting erosion of the buffer that once existed between investors and borrowers. Innovation and disintermediation have been central to the CROs' very profitable business model of the past few decades because as products grow both more opaque and increasingly

The main quantitative inputs into each agency's ratings methodology are the probability of default of individual obligors in the pool, recovery rates or losses given default, and default correlations within the pool. Default correlations deal with systematic risk and reflect the sensitivity of probabilities of default to common factors. Modeling default correlations is an analytical challenge for most CROs. BIS STRUCTURED FINANCE REPORT, supra note 5, at 17,30 . With regard to the default correlations among MBSs, the high rates of home-loan refinance instead of default from the late 1990s through 2006 may have hidden the default correlation of mortgage loans.

70. Theoretically, the CROs considered three primary qualitative factors: (1) the "bankruptcy remoteness" of the entity holding the assets from the firm that originally contributed them to the holder; (2) the quality of the management of the issuer and the services provided by the entity that services the loan (including factors such as the origination process and the comprehensiveness of loan underwriting); and (3) the integrity of the legal structure of the underlying assets. McDaniel Testimony, supra note 58, at 6 . See ERNST, supra note 58, at 6 (discussing the benefits of qualitative analysis in obtaining accurate results); BIS STRUCTURED FINANCE REPORT, supra note 5, at 16-21 (discussing structured finance rating methodology).

There is reason to doubt that these qualitative considerations were seriously undertaken. The CROs' analysis of bankruptcy remoteness has been severely criticized. See generally Kettering, supra note 56, at 1671-1710 (criticizing CROs for their "too big to fail" mentality). Likewise, for legal judgments about the underlying assets the CROs have acknowledged that they relied on the arrangers' own "representations and warranties," despite their own recognition that those representations were suspect. See McDaniel Testimony, supra note 58, at 13; see also MARJAN RIGGI, MOODY's INVESTORS SERV., THE IMPORTANCE OF REPRESENTATIONS AND WARRANTIES IN RMBS TRANSACTIONS 1 (2005), available at http://www.moodys.com/moodys/cust/research/ MDCdocs/14/2003000000447014.pdf (stating that representations and warranties only provide a "small but important" loss protection). This happened despite groups within CROs that could have taken on this task (for example, the corporate finance group at Moody's qualitatively analyzes, among other things, business strategy and management quality) and had loan-level information on factors such as the level of documented borrower income, and the CROs could have required issuers to provide audits of the underlying assets. See KrUTI MUNi \& DEEPIKA KothaRI, MOOdY's INVESTOR SERV., MOOdY'S Approach to Coding Subprime Residential Mortgage Documentation Programs: UPDATED METHODOLOGY 1 (2006), available at http:/www.moodys.com/moodys/cust/research/MDCdocs/28/2006200000425098.pdf. 
available to investors that lack strong, in-house analytic capabilities, regulators and investors rely more and more on the advice of analytical intermediaries. $^{71}$ These two developments in turn have taken place against the background of another possibly epochal trend, the deregulation of the U.S. and international financial sectors and the voluntary migration of private assets to less-regulated sectors of the economy. ${ }^{72}$ Not coincidentally, these are all implicated in the present financial crisis, ${ }^{73}$ and for that reason most observers place the three major CROs at or near its center.

First, it seems acknowledged that a wave of creative new financial products began not all that long ago, and that it continues. ${ }^{74}$ It is ordinarily said to have begun in response to increased exchange and interest rate volatility associated with the collapse of the Bretton Woods monetary system in the late $1960 \mathrm{~s}$ and early $1970 \mathrm{~s}^{75}$ As market participants faced new uncertainties, they sought both to hedge against them and to profit from them speculatively. Some have raised the fairly undertheorized suggestion that this trend is in some way "new," not just in the number or complexity of transactions, but in their substance. ${ }^{76}$ But even if the change

71. Moody's, for example, in its recent annual report for shareholders, predicts that "innovation and disintermediation will slow as capital market participants adjust to the recent poor performance of some structured finance asset classes," but "believes that the overall long-term outlook remains favorable." Moody's Corp., Annual Report (Form 10-K),

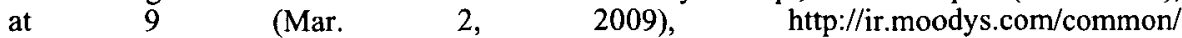
download/sec.cfm?companyid=MOOD\&fid=1193125-09-41352\&cik=1059556.

72. See COP REPORT 2009, supra note 4, for a discussion of the past thirty years of financial deregulation.

73. See, e.g., FSF 2008 REPORT, supra note 5, at 5 (arguing that the causes of the crisis, in addition to long-running boom markets and very low interest rates, included "a wave of financial innovation, which expanded the system's capacity to generate credit assets and leverage, but outpaced its capacity to manage the associated risks").

74. See Peter L. Bernstein, Capital Ideas: The Improbable Origins of Modern WALL STREET 269-306 (1992) (describing the invention of new financial products since the 1970s); Merton H. Miller, FINANCIAL InNOVATIONS AND MARKeT Volatility 3-21, $33-$ 51 (1991) (providing an overview of financial innovations from 1970 to 1990 and describing their relation to market volatility).

75. Charles R.P. Pouncy, Contemporary Financial Innovation: Orthodoxy and Alternatives, 51 SMU L. REV. 505, 549 (1998); see also SiNCLAIR, supra note 5, at 26-27 (discussing the economic changes in the post-Bretton Woods world).

76. But see, e.g., Pouncy, supra note 75, at 519-21 (noting innovative transactions dating back thousands of years). Though it is not much acknowledged, financial innovation is simply one facet of the larger phenomenon of legal innovations, which have been omnipresent in Anglo-American law. As an example, consider the development of the limited partnership with a thinly capitalized corporate general partner that is owned and controlled by the limited partners. That expedient combined flexible management, full and limited liability, and pass-through taxation at a time when that combination was supposed to be unavailable-and did so with the blessing of the courts. See, e.g., Frigidaire Sales Corp. v. Union Props., Inc., 562 P.2d 244, 245 (Wash. 1977) (holding that limited partners are not liable to creditors even if the partners serve as officers, directors, or shareholders in the corporate general partner). The complexity of that scheme pales in comparison with more 
is only one of degree, it seems that in their complexity, ${ }^{77}$ in their vast numbers and dollar amounts, ${ }^{78}$ and in the systemic risk they pose, ${ }^{79}$ the

recent transactional acrobatics meant to address multiple regulatory limits. See, e.g., Thomas F. Blackwell, The Revolution Is Here: The Promise of a Unified Business Entity Code, 24 J. CoRP. L. 333, $337 \mathrm{n} .13$ (1999) (describing a transaction where, in order to maximize limited liability, tax savings, and access to federal farm subsidies, a lawyer created seven separate, interrelated juridical entities to comprise a business that otherwise would have been a small three-man farming partnership with comparatively few assets). Having learned the hard way that lawyers will always be able to work their way out of boxes like these, most policymakers have now cried uncle, at least with respect to businessentity law. Business-entity statutes now mostly emphasize maximum possible flexibility. See, e.g., MODEL BUS. CORP. ACT $§ 7.32$ (2005) (allowing closely held corporations to do away with a board of directors, officers, and most other traditional trappings of corporate governance); REVISED UNIF. P'SHIP ACT $\S 103(\mathrm{~b})$ (1997) (providing that just a handful of provisions throughout the entire Act are nonwaivable).

Legal innovations are also very ancient. See J.H. BAKER, AN InTRODUCTION TO ENGLISH LEGAL HISTORY (3d ed. 1990) (recounting the history of the common law as mainly one of lawyerly subterfuges meant to overcome rules, including not only tax and other financial regulation, but also procedural rules in litigation, constraints on alienation of real property, forms of action, and many other areas). Plentiful other ancient examples are easy to find, such as the development of a shadow law of agency in Rome to overcome the requirement of purely personal contracting and the long history of evasion of the medieval ban on usury. See Wolfram Müller-Freienfels, Legal Relations in the Law of Agency: Power of Agency and Commercial Certainty, 13 AM. J. CoMP. L. 193 (1964); Brian M. McCall, Unprofitable Lending: Modern Credit Regulation and the Lost Theory of Usury, 30 CARDOZO L. REV. 549, 569-80 (2008).

All such innovations, financial and otherwise, reflect Pound's familiar distinction between "law in books and law in action." As he said, there sometimes comes to be a "distinction between law in the books and law in action"-some way in which the arid, theoretical law in the minds of judges and lawyers simply has not kept pace with changing society. Time and again the law has handled such a problem by adopting some new legal fiction, and Pound said that fictions "show where and how legal theory has yielded to the pressure of lay ideas and lay conduct." Roscoe Pound, Law in Books and Law in Action, 44 AM. L. REV. 12, 14-15 (1910).

77. A level of sophistication not previously seen appears to have surfaced in the 1970s. Admittedly, it was quite a while ago that Adolf Berle first wrote that the securities of his day had gotten so complex that they were difficult to value. ADOLF A. BERLE JR., STUDIES IN THE LAW OF CORPORATION FINANCE 110-13 (1928). But whereas Berle was talking about securities that now seem commonplace-convertible bonds and preferred shares with changing dividend and conversion rights-innovation since the 1960 s has involved transactions that are difficult to even conceptualize. The change arose when financial economics finally came into its own because the computing power that first became available to financial firms at that time made it possible to model and estimate risks that humans could not otherwise manage. See BeRNSTEIN, supra note 74, at 37-38; PARTNOY, supra note 53, at 15; Gilson \& Kraakman, supra note 13, at 715, 717-20 (recounting the rise and professionalization of modern finance theory, which began only about mid-century).

78. See PARTNOY, supra note 53 (setting out extensive data on magnitude of recent innovation).

79. Additionally, as recent events suggest, the current wave of innovation poses risks not just to investors but to whole economies. Financial panics have come and gone throughout the history of capitalism and at one time were comparatively routine. See generally Charles P. KINDleberger \& RoBert Z. Aliber, MANIAS, PANICS AND CRASHES: A HISTORY OF FINANCIAL CRISES (5th ed. 2005). However, since the 1970s events with systemic significance have become alarmingly frequent. In a recent speech, former Federal Reserve Chairman Paul Volcker estimated that since then they have occurred about every 
deals that have now become commonplace are unlike anything that has come before. Theorists attribute the phenomenon to many causes. A popular explanation is that it helps evade regulation, ${ }^{80}$ and although it explains much of the behavior, it cannot be the only explanation. ${ }^{81}$ At a minimum, a theory of innovation as evasion should be expanded to include all changes in exogenous financial constraints both private and public.

In any case, this recent wave of financial innovation has posed major, unambiguous problems, and some of them are centrally relevant here. First, financial innovation has been implicated in the uncommonly large number of financial crises of the past twenty years. It seems acknowledged that systemic risk in financial markets has increased, and while debate will continue as to what role financial innovation has played in that increase, it seems intuitively obvious that the evolution of very risky instruments of extremely opaque complexity, also representing very large dollar values, bear some causal relationship to it. ${ }^{82} \mathrm{Next}$, newness in and of itself necessarily frustrates risk assessment. Like all risk-assessment methods, the techniques currently available estimate risk on the basis of past performance. $^{83}$ Finally, the complexity of financial transactions now

five years. See Paul A. Volcker, Address at the Economic Club of New York (Apr. 8, 2008), available at econclubny.org/files/Transcript_Volcker_April_2008.pdf. Prior to that time, there had been none since the Great Depression. See COP REPORT 2009, supra note 4, at 8; Michael Bordo et al., Is the Crisis Problem Growing More Severe?, 32 ECON. POL'Y 53,56 \& fig. 1 (2001). For example, the use of derivatives has connected scores of parties to the performance of individual pools of MBS. Reliance upon credit ratings as triggering events for these derivatives gave the downgrade of a single MBS pool systemic reach.

80. See MiLler, supra note 74, at 5-6; S.I. Greenbaum \& C.F. Haywood, Secular Change in the Financial Services Industry, 3 J. MONEY, CREDIT \& BANKING 571 (1971).

81. For example, innovations have frequently addressed shortages in existing forms of money that could not satisfy the needs of growth. Richard Sylla, Monetary Innovation and Crises in American Economic History, in CRISES IN THE ECONOMIC AND FINANCIAL STRUCTURE 23 (Paul Wachtel ed., 1982) (describing how financial innovations addressed money shortages throughout U.S. history); Mark B. Greenlee \& Thomas J. Fitzpatrick IV, Reconsidering the Application of the Holder in Due Course Rule to Home Mortgage Notes, 41 UCC L.J. 225, 229 \& n.11 (2009). See generally JAmES WILlard HuRST, A Legal HISTORY OF MONEY IN THE UNITED STATES, 1774-1970 (1973) (detailing government involvement). Likewise, the exchange and interest rates of the 1970s are thought to have encouraged innovation for hedging purposes and coincided with the first swaps agreements. See Pouncy, supra note 75, at 527-31 (discussing the use and rise of currency swaps to transfer surplus liquidity and for hedging purposes); $i d$. at 548-56 (discussing the Bretton Woods collapse and its detrimental effect on foreign exchange and interest rates). Moreover, the argument is subject to this empirical counterpoint: U.S. financial innovation seems, by all accounts, to have exploded during the past few decades, while at the same time regulation of the U.S. financial sector has shriveled.

82. See PARTNOY, supra note 53, at 3 (arguing that risk is abundant and the "appearance of control in financial markets [is] a fiction"); COP REPORT 2009, supra note 4 , at 3, 11-19 (noting the various ways that financial risk has not been adequately regulated).

83. See PARTNOY, supra note 53, at 399-402 (discussing "value at risk" simulation and other risk-forecasting models). This causes an obvious problem. If the risks of new 
plainly represents an independent problem in and of itself. . $^{84}$

Second, disintermediation poses related problems. Bank loans were once the dominant means by which money was borrowed and lent. Banks therefore mediated between those who had funds to lend-depositors and shareholders-and those who sought to borrow them. Banks were also regulated as to their own soundness and were highly incentivized to exercise caution toward their loans because their own money was at risk. In the past few decades the picture has changed dramatically, with substantially less household wealth in traditional depositary institutions and much more of it moving to borrowers through investment funds and direct investment in debt securities and other financial instruments. ${ }^{85}$

This process is related to financial innovation in that banks find themselves, to a much greater extent than ever before, engaged in other financial-services businesses. Moreover, banks, their erstwhile depositors, and borrowers have found exposure to much more complex and risky financial products than was the case when lending was dominated by bank loans. Banks have also found innovative instruments-not only RMBS and other ABS, but also various derivatives-a more attractive means of freeing up their balance sheets and lowering regulatory capital. ${ }^{86}$

Admittedly, a case could be made that the CROs' role in the present crisis was idiosyncratic, and that the reason why CROs failed so significantly was because they had a special role in structured transactions that is unlikely to repeat itself. The very purpose of securitization is to raise money for less than would be possible if the underlying collateral were held on balance sheets. Thus, a high credit rating is a sine qua nona fact that all participants and observers freely admit. ${ }^{87}$ However, there is

products could be easily and accurately modeled based on past products, the new products would not likely be very innovative.

84. This obviously has been the case for retail consumers, but it also has been true to some significant degree for investors who should have been quite sophisticated. See id. Moreover, there is some evidence that, at least sometimes, complexity was generated for the very purpose of defrauding investors or concealing risk. See id.

85. See SinClaIR, supra note 5, at 54-57 (discussing the change to disintermediation). See generally Biagio Bossone, Do Banks Have a Future? A Study on Banking and Finance as We Move into the Third Millennium, 25 J. BANKING \& FIN. 2239 (2001) (discussing the future role of the banking industry in the context of banks' special ability to sell their own debt). A similar trend can be observed in the ways consumers save for retirement. In the past, they would collect a pension paid from a company-owned, professionally managed portfolio. Today consumers more often own, and largely design, their own investment portfolios.

86. SINCLAIR, supra note 5, at 57; see also Bossone, supra note 85 , at 2265-66 (stating how banks adapted to decreased demand in their traditional services).

87. See Petrina R. Dawson, Ratings Games with Contingent Transfer: A Structured Finance Illusion, 8 DUKE J. COMP. \& INT'L L. 381, 385 (1998) ("A structured financing seeks to insulate transactions from entities that are rated lower than the transaction, are unrated, or for which the rating is unable to quantify the likelihood of bankruptcy."); 
no meaningful reason to believe either that innovation will somehow stop, or that CROs will fail to remain at the center of innovation and its various threats. Indeed, they will actively and aggressively encourage it. Ominously, Moody's told its investors in early 2008-after the current collapse was well under way-that the company's future profitability depended on "[r]estoring investor confidence in structured products" and continued "disintermediation of financial systems." 88

\section{OVERARCHING PROBLEMS: THE ECONOMICS OF INFORMATION AND THE MISSING EVIDENCE OF VALUE}

Again, the most acute policy question in the CRO debate is whether private credit rating improves capital market efficiency or reduces systemic risk. As has now become apparent, the CROs drastically underestimated ABS risk, often because of facially apparent inadequacies in the assumptions and approaches of their risk-assessment models. ${ }^{89}$ This was only the latest in a long series of failures. Even beyond the major systemic failures of traditional corporate ratings in 2000 and 2001 and structured finance ratings in 2007 and 2008, there is evidence of overarching problems with the CRO system. As this Article will now show, none of this should be unexpected. There is, first of all, a seriously lacking theoretical basis for the existence of the CROs and for the hope that their work will provide new information to markets valuable enough to justify their substantial costs. But even if there were such a theoretical justification, the extensive empirical literature on credit ratings has failed to find much evidence that it adds valuable information to capital markets.

The question why CROs exist and whether they are likely to perform well is basically a question of industrial organization. On the one hand, no

Kettering, supra note 56, at 1564-80 (explaining the securitization process from the viewpoint of a critic).

88. 2007 Annual Report Form 10-K, supra note 20, at 3.

89. For example, CROs maintained that the default probabilities for residential mortgage-backed securities (RMBS) and CDOs were consistent with historic corporate bond performance. It was not until there were demonstrably significant differences in the performance history of RMBS and CDOs, when compared to corporate bonds, that CROs developed asset-specific default probability tables. See SEC 2008 STAFF REPORT, supra note 3 , at 36 .

This may have driven CROs to increase projected losses in 2008. For instance, in 2008 Moody's increased its projected losses on subprime RMBS significantly. In September 2008, Moody's increased its projected losses on 2006 vintage subprime pools by

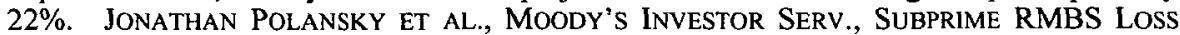
PROJECTION UPDATE 1 (2008), available at http:/www.moodys.com/moodys/cust/research/MDCdocs/18/2007300000533405.pdf. The same report illustrated that nine- to twelve-month default rates on loans rose when they had been expected to taper off from the third quarter of 2005 through the second quarter of 2007. Id. at 2 fig. 1. 
one actually knows how capital markets produce so much information and price assets so efficiently (most of the time), but it is taken for granted that it is costly for someone to gather and analyze the information. It seems to make sense that the job would involve returns to scale and that it might be best to centralize the various necessary investments in one or a few producers rather than maintain duplicative analytical capacity with each investor. This was a central claim of the original Gilson and Kraakman formulation, ${ }^{90}$ and it has been a frequent theoretical justification for the CROs. ${ }^{91}$ On the other hand, centralizing the job poses several predictable and thorny problems. An obvious problem is free riding on the publicgoods nature of information, which is exacerbated by the fact that securities research is quite costly. ${ }^{92}$ Therefore, a central difficulty is how to pay for centralized analysis. Conflicts of interest are severe when issuers pay, but collective action problems are severe when investors pay. ${ }^{93}$ We have no experience with a government-pays model of securities information, but it would likely pose significant problems of efficient investment in information (even if it were politically feasible).

Regardless of who pays, however, there will also be a severe agency cost problem. Other things being equal, intermediaries would prefer to invest less in the quality of their product. While it is commonly argued that they will thereby be penalized when the poor quality of their information is disclosed, that argument presumes competitive markets. CRO markets have been highly concentrated during the industry's entire history, a fact that may be explained by reasons other than regulatory barrier to entry. There is also no particular reason to believe that this persistently concentrated market is likely to behave competitively. If returns to scale and scope are significant and established reputation is an important asset, entry barriers might ordinarily lead to oligopolies like the one presently observed. The agency problem also probably cannot feasibly be addressed by giving intermediaries some fiduciary obligation of care because the pool of plaintiffs potentially enforcing such a duty is the entire investing public. $^{94}$ Likewise, a duty of care could theoretically be enforced by the

90. See Gilson \& Kraakman, supra note 13, at 592-609.

91. See White, supra note 5, at 43-44 (arguing that the complexity of the information needing analysis necessitates CROs); Gregory Husisian, What Standard of Care Should Govern the World's Shortest Editorials?: An Analysis of Bond Rating Agency Liability, 75 CORNELL L. REV. 411, 415-25 (1990) (outlining the various rationale for CROs' existence).

92. See supra notes $46-49$ and accompanying text.

93. See Choi \& Fisch, supra note 14 , at 278-83.

94. There is also the problem of the First Amendment as currently construed. See infra notes 134-35 and accompanying text. Admittedly, there is no reason that some sort of more enforceable civil liability scheme could not be part of an overall strategy for better intermediation. $C f$. Greenlee \& Fitzpatrick, supra note 81 (explaining how assignee liability can incentivize care); see also infra Part VI.C. The point here is that merely making it 
government, perhaps by establishing minimum standards all CROs must meet when evaluating issues. This simple solution, however, ignores the immense challenge the government would face in reviewing the roughly 20,000 new ratings issued each year by each of the major CROs. Even if the government only investigated ratings about which it received complaints, which would still require significant resources, the issue of creating effective penalties for violations of a duty of care still poses a significant problem. In short, it is very hard to imagine how an intermediary service could be organized so as both to fully compensate an efficient amount of investment in analysis and ensure its quality.

An even more significant problem is that the basic argument above--the argument that information gathering is so costly and likely to favor scale that there must be institutional intermediaries-begs a serious empirical question. Markets themselves are machines for generating information, and from the viewpoint of some finance economists, they ought to be really good at it. ${ }^{95}$ While the major CROs are often privy to nonpublic disclosures from the issuers they rate and have a special regulatory dispensation to receive it, the major CROs sometimes, and the smaller CROs almost always, base their ratings only on public information. ${ }^{96}$ That

easier for individual investors to sue the CROs for negligent ratings will pose the same problems that have burdened shareholder securities litigation generally. It is extremely difficult, to say the least, to strike a balance between a penalty that is economically meaningful enough to discourage CROs from allowing the quality of their ratings to slack and not so economically burdensome that the business of issuing credit ratings would no longer be economically viable. In any case, economically meaningful penalties are likely to drive up the cost of credit ratings. Unless such penalties improve the accuracy of credit ratings, this increased cost will further diminish the actual value credit ratings add to markets. There also likely would remain the problematic need to make out a culpable mental state and the persistent judicial perception that shareholder suits are frivolous. See infra notes $157-67,198$ and accompanying text. Of course, any government-enforced standard does nothing to make whole those actors who rely on credit ratings when making investment decisions. The argument that relying on credit ratings when making investment decisions is inherently unreasonable, an argument which many courts inexplicably accept, is off base in a regulatory environment that requires investors to rely heavily on credit ratings when making investment decisions.

95. To wit, the unassailable orthodoxy among finance economists from the 1960 s until fairly recently was that modern capital markets approximate perfect efficiency, meaning that the pricing of capital assets very quickly and very completely incorporated all relevant information. See generally ANDREI SHLEIFER, INEFFICIENT MARKETS: AN INTRODUCTION TO Behavioral FinanCE 1 (2000). That hypothesis, as Shleifer explores at great length, is now in doubt.

96. The "dispensation," again, is that in the United States the NRSROs are exempt from Regulation FD. See supra note 28 . Moreover, as to whatever nonpublic information they receive and incorporate into their ratings, they depend entirely on issuers for its reliability and have no mechanism for enforcing honest disclosure. For example, evidence is surfacing suggesting that arrangers did not disclose reports about the declining loan quality in pools of RMBS to CROs. See, e.g., Chris Amold, Auditor: Supervisors Covered Up Risky Loans, NAT'L Pub. RADiO, May 27, 2008, 
is, there is not actually that much of a theoretical basis for the view that market participants cannot simply do for themselves what the CROs do, all on the basis of publicly available data.

In any case, wholly aside from the lack of a theoretical foundation, there is also a lack of empirical evidence of the value that is supposedly added by private credit ratings. While highly rated bonds have low default rates and enjoy yields consistent with low risk, ${ }^{97}$ and while some commentators take this as evidence of the CROs' successful performance, ${ }^{98}$ the evidence suggests that at best they just barely meet the markets' own success at predicting bond values. Hickman's pioneer study found that during the first half of the twentieth century, when the instruments under review were much simpler than they are now and bond markets were working extremely well, the CROs did only about as well at predicting defaults as did the markets themselves. ${ }^{99}$ While arguably the results have been somewhat mixed, extensive empirical literature dating to the late 1950s has failed to find more than a small portion of bond price and yield performance that cannot be explained on the basis of simple, publicly available financial data. $^{100}$ Moreover, post-issue ratings changes are particularly uninformative. The single most robust and well-tested empirical result has

http:/www.npr.org/templates/story/story.php?storyId=90840958; Patrick Rucker, Wall Street Often Shelved Damaging Subprime Reports, REUTERS, July 27, 2007, http://www.reuters.com/article/businessNews/idUSN2743515820070727.

97. See HiCKMAN, supra note 34, at 7-12; Louis H. Ederington \& Jess B. Yawitz, The Bond Rating Process, in HANDBOOK OF FINANCIAL MARKETS AND INSTITUTIONS 41 (Edward I. Altman ed., 6th ed. 1987) (canvassing prior studies and concluding that approximately two-thirds of new issue ratings can be predicted on the basis of a handful of publicly available accounting measures); Richard R. West, Bond Ratings, Bond Yields and Financial Regulation: Some Findings, 16 J.L. \& ECON. 159 (1973); see also Lawrence Fisher, Determinants of Risk Premiums on Corporate Bonds, 67 J. POL. ECON. 217 (1959) (finding that about three-quarters of risk premiums on corporate bonds studied could be explained by simple, publicly available financial data); Pu Liu \& Anjan V. Thakor, Interest Yields, Credit Ratings, and Economic Characteristics of State Bonds: An Empirical Analysis, 16 J. MONEY CREDIT \& BANKING 344 (1984) (concluding that while ratings themselves have a statistically significant, independent effect on yield, straightforward economic factors reliably predict municipal bond ratings).

98. See, e.g., Rousseau, supra note 10, at 631; Schwarcz, supra note 10, at 13-14.

99. See HICKMAN, supra note 34 , at 7-12 (determining that bond markets performed remarkably well during the first half of the twentieth century, notwithstanding its many disruptions). As a check on his results, Hickman matched them against CROs' predictions of default risk and found them to track closely with market-derived yield spreads. See generally Sylla, supra note 16, at 12-13 (summarizing Hickman's results and their significance for measuring the CROs' performance).

100. See supra note 96. The results are "mixed" only in that researchers have been unable to explain all bond performance variation. The as-yet unexplained variation might reflect some informational value in ratings. Importantly, even if the unexplained variation is associated with ratings, some of that effect is to be explained by the purely regulatory effect of "fallen angels"-bonds being downgraded from investment- to speculative-grade. See West, supra note 97. 
been that bond prices and returns tend reliably to anticipate ratings changes some months before the change. ${ }^{101}$ Furthermore, substantial literature shows that ratings changes can be predicted using simple ratios based on publicly available financial statements. ${ }^{102}$ Even when ratings changes are not anticipated by the market, there is only a significant change in price when downgrades occur, which may simply reflect the increased funding costs that accompany lower credit ratings. Empirical evidence also suggests that investors find ratings to be of little intrinsic value. ${ }^{103}$

Finally, the operation of the dominant CROs under the two-rating norm and the issuer-pays model, along with the distortions caused by the NRSRO designation, have been very expensive. Even if CROs perform exactly as well as other market measures, any cost advantages of their particular form of organization would have to be truly significant to explain their large fees and justify their extensive use by policymakers.

101. See Covitz \& Harrison, supra note 10; John R.M. Hand et al., The Effect of Bond Rating Agency Announcements on Bond and Stock Prices, 47 J. FIN. 733 (1992); Gailen Hite \& Arthur Warga, The Effect of Bond-Rating Changes on Bond Price Performance, 53 FIN. ANALYSTS J. 35 (1997) (arguing that other interesting effects that have repeatedly been shown are that the "pre-announcement effect" is much stronger for downgrades than for upgrades, and that the effect is much more pronounced as to bonds that are already poorly rated); Mark I. Weinstein, The Effect of a Rating Change Announcement on Bond Price, $5 \mathrm{~J}$. FIN. ECON. 329 (1977). Ratings changes are similarly anticipated by stock price changes. See George E. Pinches \& J. Clay Singleton, The Adjustment of Stock Prices to Bond Rating Changes, 33 J. FIN. 29 (1978) (stating that ratings changes are similarly anticipated by stock price changes). At least one recent study argues that CRO ratings add value by insuring against bad equilibriums, especially after a firm has been placed on a credit watch. See Arnoud W.A. Boot, Todd T. Milbourn, \& Anjolein Schmeits, Credit Ratings as Coordination Mechanisms, 19 REV. FIN. STUD. 81 (2006). However, the authors concede a few points that significantly detract from this assertion. First, ratings only add value if a significant portion of institutional investors "agree" with the rating by purchasing the securities, suggesting that it is their participation, and not the rating, that adds information to the market. Second, they argue that credit ratings are most valuable when institutionalinvestor beliefs are divergent, while also pointing out that if beliefs are too divergent, credit ratings will no longer play a coordinating role. If it were truly the ratings rather than the institutional-investor behavior acting as a market coordinator, then the coordinating role of credit ratings should not break down when institutional-investor beliefs diverge.

102. See, e.g., Chan \& Jegadeesh, supra note 10, at 156-58, 163-68 (summarizing relevant literature and providing new findings on the different approaches used to predict bond ratings).

103. See H. Kent Baker \& Sattar A. Mansi, Assessing Credit Rating Agencies by Bond Issuers and Institutional Investors, 29 J. BUS. FIN. \& ACCT. 1367 (2002) (reporting survey evidence that demonstrates that the majority of institutional investors rely more on in-house analysis than CROs' reports); David M. Ellis, Different Sides of the Same Story: Investors' and Issuers' Views of Rating Agencies, 7 J. FIXED INCOME 35 (1998) (noting survey evidence of investor skepticism of CROs' ratings). 


\section{OTHER OVERARCHING PROBLEMS WITH THE CROS AS THEy EXIST}

\section{A. Conflicts of Interest}

Policy discussions on the CROs usually begin with conflicts of interest. The issuer-pays model is the most frequently identified conflict, and indeed, the SEC nominally identifies issuer-pays as a "conflict of interest" as a matter of law. ${ }^{104}$ As a matter of fact, notwithstanding that for many years the major CROs have all maintained procedures and internal conduct codes designed to constrain conflicts, new evidence suggests that, at least in recent years, conflict problems were rife. ${ }^{105}$

Changes in the concentrated, disintermediated U.S. banking industry have exacerbated these problems. It may be true, as the CROs often claim, that the fee charged for any one rating is too small a portion of overall revenue to create a conflict. However, U.S. investment banking is now so concentrated that a handful of firms are responsible for arranging and underwriting the bulk of large new debt issues, and they typically select the CRO. ${ }^{106}$ This is borne out in internal CRO conversations about retaliation by issuers for unfavorable ratings treatment. ${ }^{107}$

104. See Securities Exchange Act, 17 C.F.R. $\S 240.17 g-5(b)(1)$ (2008) (prohibiting all "conflicts of interest" and defining issuer-pays as a conflict of interest, with the exception of conflicts that are disclosed in filings with the SEC so long as the NRSRO maintains some internal conflict-of-interest policy).

105. As highlighted in the SEC 2008 Staff Report, some CROs' analysts have still participated in fee discussions with issuers. Likewise, while bonuses are determined by individual performance and the overall success of the firm rather than ratings, analysts are aware of the CROs' interest in securing individual ratings deals and market share, and have considered these factors when making ratings methodology decisions. See SEC 2008 STAFF REPORT, supra note 3, at 24-26.

The SEC staff also found evidence of CROs' analytical staff taking specific actions possibly driven by such conflicts. For instance, CROs would also make adjustments outside of their ratings models without documenting the rationale for the adjustment. Id. at 14 (showing that these adjustments appear to have raised ratings, and "[o]ne rating agency regularly reduced loss expectations on subprime second lien mortgages from the loss expectations output by its RMBS model, in some cases reducing the expected loss"). CROs also failed to consistently document committee composition, actions, and decisions. Often missing from CROs' documents were vote tallies from rating-committee rating votes, documentation of any ratings surveillance, committee memos or minutes, or both, and other relevant documentation even when required. There was, at times, no documentation of committee attendees. See id. at 19-20.

106. As to structured products, for example, the CROs were heavily dependent on fees from a small number of arrangers within the concentrated U.S. investment banking industry. See id. at 32 (finding that twelve arrangers accounted for nearly all of one large sample of structured deals rated by the major CROs). The banking industry has already concentrated further since the downturn of early 2008 , and yet more failures and consolidations are widely expected. Until the credit collapse that began in mid-2007, a huge and rapidly growing portion of the major CROs' revenues comprised fees from rating securitized bonds issued by a handful of major banks.

107. Privately, CROs express concerns that methodology or modeling changes will 
Likewise, financial innovation introduces a wholly new conflict of interest, and at the same time it makes the job of prospective credit rating more difficult-or as some critics say, impossible. Financial-market acceptance of some innovative product can promise large returns to the CROs, ${ }^{108}$ incentivizing CROs to encourage that acceptance. In the case of structured products, they have gone out of their way to do so. ${ }^{109}$ Critics who have long claimed that the CROs overrated structured products may now be vindicated. ${ }^{110}$ For instance, there is evidence that CROs themselves believed they should not have been rating some structured products. ${ }^{11}$

drive away business, and they have considered revisiting ratings methodology in order to recapture market share from other CROs. See id. at 25-26. For instance, one employee stated " $[w]$ are meeting with your group this week to discuss adjusting criteria for rating CDOs of real estate assets this week because of the ongoing threat of losing deals." Id. (citation omitted). Another employee responded, stating that aspects of the ratings methodology would have to be revisited to recapture market share from another CRO. Id. Moreover, at least one CRO has allowed deals in the process of being rated to use old rating criteria when new rating criteria had been introduced. Id. at 32 .

108. The revenues CROs received from rating RMBS and CDOs substantially increased from 2002 to 2006. In each year from 2004 to 2007, the three major CROs saw their revenue from such ratings increase between $50 \%$ and $150 \%$ when compared to the same revenue stream in 2002. Id. at 10-11. In 2006, when the revenue from rating RMBS and CDOs was at its highest, Moody's generated \$6 million per employee. See Gerard Caprio, Jr. et al., The 2007 Meltdown in Structured Securitization: Searching for Lessons Not Scapegoats 19 (World Bank, Policy Research Working Paper No. 4,756, 2008); Buttonwood: Credit and Blame, ECONOMIST, Sept. 8, 2007, at 77 (noting that CROs experienced revenue increases of $\$ 754$ million); see also Moody's Corp., Annual Report (Form 10-K), at 21 (Mar. 1, 2007), http://ir.moodys.com/common/ download/download.cfm?companyid=MOOD\&fileid $=165514 \&$ filekey $=$ E3CB9ABB-700C46FF-B2CA-DF3296084E4F\&filename $=200610 \mathrm{~K}$.pdf (documenting that in 2006 more than $45 \%$ of Moody's revenue was generated from rating structured-finance products, such as RMBS and CDOs); Gretchen Morgenson, Debt Watchdogs: Tamed or Caught Napping?, N.Y. TIMES, Dec. 7, 2008, at Al (reporting that fees received for rating structured-finance products far exceed other products, and that as such ratings increase, so do CROs' operating margins).

109. From 2003 to 2007, S\&P, for example, actively publicized evidence that they much more frequently upgraded their ratings of subprime MBSs than they downgraded them, thereby urging investor confidence in these untried new products. See Kathleen C. Engel \& Patricia A. McCoy, Turning a Blind Eye: Wall Street Finance of Predatory Lending, 75 FORDHAM L. REV. 2039, 2055-56 (2006) (surveying S\&P's own public statements as to its upgrade and downgrade activity). S\&P's claims in this literature were doubly misleading. First, CROs in fact almost never changed their ratings of MBSs or other securitized products until mid-2007, when they downgraded masses of them. The few hundred ratings changes discussed in the 2003-2007 literature represented a tiny fraction of the tens to hundreds of thousands of such ratings they had issued. Second, as we shall see in some detail below, the CROs in fact did not make initial ratings that were at all conservative and, by and large, seem now to acknowledge that their ratings of these products were substantially overoptimistic. See infra note 116 and accompanying text.

110. See, e.g., AAAsking for Trouble, ECONOMIST, July 14, 2007, at 77; Sold Down the River Rhine, ECONOMIST, Aug. 11, 2007, at 66 (showing that some of these tranches were originally rated only a year or two before the downgrade, prompting comments that the sudden downgrade was a "belated recognition that such ratings always were a bit dubious").

111. In April 2007, correspondence between two CRO analysts emerged. One analyst 
Moreover, working relationships have been much closer in the context of structured finance ratings where CROs work with issuers to reach a rating satisfactory to the issuer. ${ }^{112}$ This arrangement mirrors the way that accounting firms sold their clients management-consulting services before Sarbanes-Oxley prohibited the practice because of the conflicts of interest it created.

The CROs have sought to discount these problems on several grounds, but none so far seems availing, especially in light of their recent failures. They have long claimed that their internal procedures adequately contain conflicts, but recent evidence suggests those procedures were not effective. ${ }^{13}$ They also defend their roles in various crises by pointing to their disclosures and warnings to investors, ${ }^{114}$ but their warnings were apparently undercut severely by the fact that even as they issued warnings, they continued to rate very risky securities with very high ratings. ${ }^{115}$ Other

criticized a deal by calling it ridiculous and advising against rating it. While those statements seem responsible, the reply received was "it could be structured by cows and we would rate it." Another senior analytical manager wrote that CROs were creating an "even bigger monster-the CDO market. Let's hope we are all wealthy and retired by the time this house of cards falters." SEC 2008 STAFF REPORT, supra note 3, at 12.

112. Securities issuers have some incentive to ensure a range of ratings on any one pool of securities issued so tranches can be sold to investors seeking various levels of risk and return. There is a much larger market for investment-grade-rated senior tranches than there is for other tranches because that rating allows sales to portfolio-constrained institutional investors. See The Use and Abuse of Reputation, ECONOMIST, Apr. 6, 1996, at 18; Who Rates the Raters?, supra note 61 , at 67 . The senior tranches are also the least expensive to fund due to their low coupon rate. Thus, arrangers generally attempt to create the largest possible senior tranche. SEC 2008 STAFF REPORT, supra note 3 , at 8.

Assuming a credit rating is in fact value added, it is theoretically not inappropriate for CROs to work with arrangers to structure products for high ratings insofar as CROs are simply explaining how to optimize the structure of pools. But many have persuasively argued otherwise. See, e.g., Who Rates the Raters?, supra note 61 , at 68 (citing to parallels to the conflicts to which the auditing industry fell victim in recent history).

113. See supra note 45 and accompanying text.

114. See, e.g., McDaniel Testimony, supra note 58, at 1 (claiming that Moody's warned investors about deterioration in origination standards and inflated housing prices as early as 2003).

115. In March 2008, Bloomberg reported that Moody's and S\&P were holding off on downgrading investment-grade-rated MBS pools. By the time of the article, Moody's and S\&P downgraded nearly 10,000 subprime-mortgage tranches without publicly addressing investment-grade-rated tranches. At the same time, evidence suggested that nearly $\$ 120$ billion in investment-grade-rated bonds should have been downgraded if the companies followed their own formulas. See Mark Pittman, Moody's, S\&P Defer Cuts on AAA Subprime, Hiding Loss, BLOOMBERG, Mar. 11, 2008, http://www.bloomberg.com/apps/news?pid=20670001\&sid=areM7a9s02ko. A month later, Moody's downgraded nearly 2,000 tranches in two days. See Paul Jackson, Stick a Fork in It: Moody's Downgrades 1,923 Subprime RMBS Classes-In Just Two Days, Housing WIRE, Apr. 22, 2008, http://www.housingwire.com/2008/04/22/stick-a-fork-in-it. The fact that such a high percentage of the mortgages in these pools were defaulting or going into foreclosure one to two years into a thirty-year maturity period calls into question their initial investment-grade ratings. 
attempts to discount conflicts seem similarly flawed. ${ }^{116}$

Finally, the CROs argue that whatever its downsides, issuer-pays makes ratings available to the entire public at no cost, reducing the advantages of wealthy investors. ${ }^{117}$ Whatever benefits that may produce, accuracy of the ratings is more important than their wide availability, especially given their incorporation into portfolio rules. Moreover, large investors will retain advantages, such as in-house analytical capabilities, despite the availability of credit ratings. Individuals would be better served by the availability of more accurate ratings to the institutional investment managers who invest on their behalves.

\section{B. Doubts About "Reputational Capital"}

The CROs and their defenders argue that the best assurance of their integrity is their need to preserve "reputational capital," an argument that is at odds with the recent evidence. ${ }^{18}$ There are also several other reasons to doubt this argument. First, the major CROs have until very recently enjoyed the significant entry barrier of NRSRO designation and, as will be argued later, would probably enjoy significant entry protection in its absence as well. ${ }^{119}$ Therefore, because of this lack of effective price

116. Moody's, for example, argues that regardless of who pays for ratings, investors would be motivated to encourage inflated ratings to improve the marketability of their bonds, to improve their existing portfolio values, or to establish new portfolio positions. See McDaniel Testimony, supra note 58, at 8-10. This seems very implausible. Under an investor-pays model, even assuming investors could exert the same influence as issuers, different investors have different incentives and would thus pressure the CROs differently. Moreover, institutional buyers constrained by fiduciary duties would not desire artificially inflated ratings because paper gains have no intrinsic value to those investors, and may actually be liablilities.

Moody's argues that because investors are frequently also issuers, there is no meaningful distinction between them. See id. at 9 . First, one cannot help but wonder why CROs have expressed such a strong preference to have issuer-pays if there is no meaningful distinction between investors and issuers. This position only makes sense if every issuer is the exclusive investor in its own issue. Otherwise, the issuer and investor are meaningfully distinct. As to more complex products, in particular, the issuer knows more about the quality of the assets than the investor, and CROs are supposed to help reduce that asymmetry. The investors most in need of guidance from CROs would seem to be those without sufficient in-house analytical capacity of their own, but that likely describes a large number of buy-side investors. Finally, a large number of investors simply are not issuers, and so Moody's argument really just begs a large empirical question: whether the interests of the buy side and sell side are evenly enough matched to make conflicts a wash. Impressionistically, it seems like the assumption implied is wrong.

117. See id.

118. See supra notes 104-07, 111 and accompanying text (documenting internal evidence from CROs of gross conflicts of interest and the rating of products that CRO staff believed to be unratable).

119. See infra note 148 and accompanying text. A minor puzzle might seem to be that, while reputational capital has not been a meaningful constraint on CRO behavior, the establishment of reputation works as an entry barrier. And yet both things seem to be the 
competition, the lethargy characteristic of monopolies may shield them from competitive pressures that otherwise would encourage service quality. ${ }^{120}$ Second, CROs are likely susceptible to the "herd" behavior for which there is now growing evidence in financial markets. Analytical intermediaries apparently fear individual mistakes much more than collective ones. Moreover, empirical evidence suggests that securities analysts' career prospects are improved more by systematic overoptimism than by accuracy, a fact that may influence the work of CROs' analytical staffers. ${ }^{121}$ Third, the extensive documentation of conflicts of interest within the CROs is strong counterfactual evidence to the hypothesis that the need to preserve reputational capital is an adequate check on their behavior.

There is often no particularly good reason to believe that a given issuer needs a reputational intermediary at all, especially one as expensive as the major CROs. Major debt issuers can anticipate frequently repeated interactions in debt markets and will forecast the need for low-cost debt funding far into the foreseeable future. ${ }^{122}$ Also, reputational constraints should have been important for the major auditing firms as well, but recent events have shown that to have not been the case. ${ }^{123}$

\section{Resource Constraints: Coping with Complexity and Rapid Change}

Resource constraints have been a running problem, and they may be to blame for some of the worst problems in the ratings of structured products. The long-standing criticism of inadequate analytical staff ${ }^{124}$ became severe

case. A likely explanation is based on network effects. Despite evidence that investors do not value the information content of ratings, see supra note 103 , they incorporate the ratings of specific CROs in private contracts and private portfolio investment rules. While it remains an empirical question why precisely they do so, it seems likely that a CRO's "reputation" can have some consequences beyond any marketplace confidence in the informational value of its work.

120. See generally RiCHARD A. POSNER, ANTITRUST LAW 18-22 (2001).

121. See David S. Scharfstein \& Jeremy C. Stein, Herd Behavior and Investment, 80 AM. ECON. REV. 465 (1990), for the preeminent research and discussion on "herding." See also COFFEE, supra note 14, at 252-53, for detailed empirical research on the subject. When rating complex derivative products, herding had a significant upside for the CROs, while failing to do so had a downside. For example, some smaller CROs did not rate CDOs because, they claim, CDOs made no sense. Yet, the major CROs profited immensely from rating $\mathrm{CDOs}$ until the market discovered how poorly the ratings reflected CDO risk characteristics. Since then the market has evaporated and the only effect not participating in the CDO rating market had on smaller CROs was that they had no opportunity to generate revenue from rating CDOs during the boom.

122. See Partnoy, supra note 14, at 500-01 (arguing that there will be a continuous need for low-cost debt financing).

123. See COFFEE, supra note 14 (describing the complicity of the major auditing firms in corporate accounting scandals since 2000).

124. See, e.g., Partnoy, supra note 11, at 651-52 (discussing structural problems modern 
during the explosion of structured finance, despite the CROs' substantial growth during the three decades prior. ${ }^{125}$ Their due diligence as to these products was often poor or nonexistent, ${ }^{126}$ and there is evidence that the CROs have sometimes been pressured by their clients into acting too quickly. ${ }^{127}$ They also failed to devote sufficient resources to surveillance efforts. ${ }^{128}$ All this suggests that even the major CROs cope poorly with

CROs exhibit in the quest for reputational capital).

125. The growth of asset-backed securities from 2002 through 2006 created a demand for credit ratings that CROs could not match. See SEC 2008 STAFF REPORT, supra note 3, at 10. The SEC determined that limited resources were allocated to structured-finance groups that focused on rating RMBS and CDO issues. Internal CROs' e-mails describe the situation as tense. An e-mail from a senior business manager states that there was "too much work, not enough people." Id. at 12. An e-mail from an analytical manager fleshed out the picture, stating, "“[W]e ran our staffing model assuming the analysts are working sixty hours a week and we are short on resources ... . The analysts on average are working longer than this and we are burning them out. We have had a couple of resignations and expect more." Id. (footnote omitted).

126. CROs acknowledge that originator practices could have a potentially large impact on loan performance. See SIEGEL, supra note 59, at 2 ("Moody's continues to believe that differences in originator practices and loan programs have the potential to have a large influence on loan performance ....."); see also id. at 7 ("[I]t is important to examine the quality of originator practices, particularly efforts to verify data through appraisals, credit checks, and other means."). Nonetheless, they argued that they could assess such risks through quantitative analysis, supplemented by superficial qualitative analysis. See MUNI \& KOTHARI, supra note 70, at 1 . In fact, the three major CROs did not engage in due diligence or otherwise verify the accuracy or quality of the loan data they reviewed. SEC 2008 STAFF REPORT, supra note 3, at 18 . Instead, they relied on information provided to them by sponsors, which was provided to them without representations that the sponsors had performed any sort of due diligence. Id. at 18. Moreover, the documentation required for assets underlying rated structured securities fell over time-from 2002 to 2005, the percentage of subprime loans rated by Moody's that fully documented borrower income fell from $72 \%$ to $55 \%$. MUNI \& KOTHARI, supra note 70 , at 2 . It was not until 2008 , after the SEC published a report that noted these missteps and RMBS issuance was nearly nonexistent, that CROs implemented more extensive reviews of originator practices. SEC 2008 STAFF REPORT, supra note 3, at 18.

127. See SEC 2008 STAFF REPORT, supra note 3, at 32. Arrangers, who are paid in part based on the volume of deals they put together, push for a fast ratings process. See $i d$. This may have influenced a CRO to allow deals that were in the ratings process to continue to be rated with old criteria, despite the introduction of new criteria by CROs during the rating. Id.

128. See, e.g., Kettering, supra note 56, at 1674 . This played out in recent corporate bond markets, where Enron and WorldCom were rated investment-grade until days before the collapse of the companies. Who Rates the Raters?, supra note 61, at 68-69 (noting that by the time the Enron downgrade was issued, most bad news had come out and Enron's share price had dropped dramatically). A recent SEC report revealed that two of the three major CROs poorly or completely failed to document any monitoring of CDOs and RMBSs. SEC 2008 STAFF REPORT, supra note 3, at 21-22 (noting that CRO surveillance efforts were lacking in timeliness and diligence). This may not be surprising considering two of the big three CROs had not created internal documents containing the steps necessary to monitor CDOs and RMBS. Id.

In fact, as to structured products, the CROs apparently relied mainly on pool-level triggers to alert them that the credit quality of the pool had significantly declined. A rating committee will only be convened to reevaluate a rating if it appears that an issuer may be at 
rapid innovation. ${ }^{129}$

\section{What CONSTRAINTS AT PRESENT?}

Assuming there is something in the CROs' work that should be done better or be better constrained, it should first be asked whether any existing laws might be better suited to accomplish this. We think it is unlikely.

\section{A. Big-Picture Basics, or What Exactly Are the CROs?}

\section{Are CROs the "Government"?}

CROs perform functions that are government-like. In one respect, those CROs with NRSRO designation make what is literally de jure law: they decide, as a matter of law, whether particular assets may be owned by particular regulated entities. Likewise, in the structured-finance context, the NRSROs took on the special role of helping issuers prestructure their deals to ensure the desired ratings for top-tranche securities. In other words, they made essentially regulatory calls as to the internal structure of

a credit rating inconsistent with its peers. The primary trigger used was an overcollateralization test, which measured a pool's total losses against the total dollar value of credit enhancements. See id. at 36. The pool was considered unimpaired by losses as long as the pool contained collateral in excess of the pool's total payment obligations to investors. Conceptually this is a puzzling trigger, as it asserts that a pool with a payment horizon of thirty years can lose $99 \%$ of its overcollateralization in the first year without being a bigger credit risk than it was when created. While defaults on mortgage payments tend to become less frequent with the passage of time, one would think a pool rapidly eating through overcollateralization would signal a potential downgrade, or at least land it on a socalled CRO watch list (which the major CROs maintain to publicize the fact that a downgrade is under consideration). When credit enhancements come in the form of issuers guaranteeing portions of the senior tranches, this trigger becomes even more tenuous. This is because the actual value of those guarantees, especially when given by a single issuer, may not equal the full amount of the guarantees. See BIS STRUCTURED FINANCE REPORT, supra note 5 , at 28 , for a discussion about the problems with mono-line issuers providing pool credit enhancements.

129. The complexity of structured products was apparently beyond even the largest CRO's ability to keep up. The process of arranging and rating a pool of assets creates information frictions at most steps in the process and poses a major lemons problem in the CROs' ratings. See generally Adam B. Ashcraft \& Til Schuermann, Understanding the Securitization of Subprime Mortgage Credit, FED. RESERVE BANK OF N.Y. STAFF REP., Mar. 2008.

One other major problem with their handling of innovative products is lack of data. The fundamental objective aspect of their approach, quantitative risk assessment, depends heavily on historical data, but as to innovative products, such data will often be unavailable. For example, CROs were rating "affordability products" like pay-option adjustable-rate mortgages (ARMs) and interest-only (IO) loans when there was not much historical performance data on these loans from any originator. PETER MCNALLY, MOODY'S INVESTORS SERV., UNDERSTANDING METRICS FOR PERFORMANCE MONITORING, VOlume 3: RESIDENTIAL MORTGAGE-BACKED SECURITIES 6 (2005), available at http://www.moodys.com/moodys/cust/research/MDCdocs/14/2004300000425487.pdf. 
particular financial transactions. Therefore, a natural question is whether their quasi-government status renders them subject to any special liabilities, defenses, or privileges.

By prevailing orthodoxy, the answer is plainly no. All U.S. CROs and most foreign ones are private, profit-making entities, and the three U.S. majors are publicly traded corporations or subsidiaries thereof, organized under state corporate laws. ${ }^{130}$ Therefore, despite their influence and the federal deputy stars they wear, it is basically inconceivable that they could be subject to the federal constitutional or administrative rules that govern proper agencies. ${ }^{131}$ Likewise, because they are not federally chartered and do not formally advise or contract with the SEC or other agencies, they are free of the open-government constraints that bind some quasi-public entities. ${ }^{132}$ This special status in between public and private is not unique to the CROs. In any number of other contexts, the government has fumbled around in search of a policy and has managed to deputize some private group to take care of it. In those cases the group will typically be neither democratically accountable, nor subject to public law constraints, nor especially well regulated by private law liability. ${ }^{133}$

\section{On the Contrary, They Are Just Regular Folks Speaking Their Minds}

Not only are CROs not the government in the eyes of the courts, but they enjoy some First Amendment protection for their ratings. Several courts have held that various claims of liability against CROs must fail as in

130. See supra notes 20-22.

131. Even where an entity is created by federal statute and subject to some federal governance role, it may not be the "government" for constitutional and administrative law purposes. Compare Reg'l Rail Reorganization Act Cases, 419 U.S. 102 (1974) (holding that the Conrail entity, a corporation created by federal statute and subject to substantial federal control, was not a "federal instrumentality"), with Lebron v. Nat'l R.R. Passenger Corp., 513 U.S. 374 (1995) (finding that the Amtrak entity, also a corporation created by federal statute and subject to substantial federal control, was a federal instrumentality and could be subject to the First Amendment). A fortiori the CROs have no direct government involvement at all.

132. For example, see the Government Corporation Control Act, 31 U.S.C. $\S \S 9101-$ 9110 (2006), or the Federal Advisory Committee Act, 5 U.S.C. app. $\S \S 1-15$ (2006).

133. See, e.g., A. Michael Froomkin, Wrong Turn in Cyberspace: Using ICANN to Route Around the APA and the Constitution, 50 DUKE L.J. 17 (2000) (describing the improbable rise of the Internet Corporation for Assigned Names and Numbers as the U.S. federal government's wholly private means for controlling the very root systems of the Internet); Chris Sagers, The Myth of "Privatization," 59 ADMIN. L. REV. 37 (2007) (describing the range of entities with quasi-governmental powers but comparatively little oversight); Chris Sagers, The Evolving Federal Approach to Private Legislation and the Twilight of Government (Cleveland-Marshall Coll. of Law, Working Paper No. 05-117, 2005), available at http://ssrn.com/abstract $=610587$ [hereinafter Sagers, Twilight] (describing the similar power of standard-setting organizations in many contexts). 
violation of the First Amendment. ${ }^{134}$

The very fact of this constitutional result is a large enough problem in itself. A frequent problem when applying First Amendment protection to commercial behavior is the failure to consider the consequences of mischaracterization of the entity seeking protection. ${ }^{135}$ However, even under the assumption that such protection exists, the problem for the rest of this analysis is that regulatory instruments must contend with the risk that they are unconstitutional as applied to privately generated credit ratings.

\section{But Are They Standard Setters?}

Finally, one interesting and different issue is that CROs fill a role similar to that of a whole class of other nominally private entities commonly known as standard-setting organizations (SSOs). Like most SSOs, the CROs establish a more or less codified policy that is binding on other private actors by establishing formal normative guidelines of their own and encouraging compliance with them. ${ }^{136}$ The federal government has shown a fairly keen interest in SSOs, and the scattered body of policies and rules developed for them contain some slender limits that might marginally improve the behavior of the CROs. ${ }^{137}$ But it seems unlikely that any of those policies would actually apply, ${ }^{138}$ and while it might improve credit ratings in some respects, it would still leave the industry with serious problems. $^{139}$

134. These issues are pursued at greater length in Chris Sagers, Further Perversions in First Amendment Characterization and the Metaphysics of Corporate Nature: The Case of the Bond Rating Agencies (manuscript on file with the authors).

135. See generally id.; Christopher L. Sagers, The Legal Structure of American Freedom and the Provenance of the Antitrust Immunities, 2002 UTAH L. REV. 927, 951-57 (examining the negative unforeseen consequences of well-intended extensions of First Amendment protection to juridical persons).

136. See Sagers, Twilight, supra note 133, for a fuller account of federal oversight of private standard setting.

137. Namely, the federal government has provided that it will make use of privately adopted "standards" in both procurement and in regulation, but only if those standards are adopted according to "consensus" procedures. Consensus procedures are those in which affected persons are given an opportunity to participate in the standard-setting process and afforded fairly substantial procedural protections. See Sagers, Twilight, supra note 133. In a move only too familiar from CRARA and the SEC regulations under it, the consensus procedures effectively mandated by the government are precisely those that had already been in use by the most powerful SSOs for many years. See id.

138. This is so both because the work of CROs probably does not fit the definition of "standard" currently in use in federal policy and because CROs are now separately regulated by CRARA. See National Technology Transfer and Advancement Act of 1995, Pub. L. 104-113, $\$ 12$ (c)-(d), 110 Stat. 775, 783 (1996) (codified at 15 U.S.C. $§ 272$ note); Federal Participation in the Development and Use of Voluntary Consensus Standards and in Conformity Assessment Activities, 63 Fed. Reg. 8,546 (Feb. 19, 1998) (implementing the Technology Transfer and Advancement Act).

139. Credit rating might be improved if CROs were forced to develop their 


\section{B. CRARA and SEC Oversight: Free-Market Competition Solutions Are Doomed}

With regard to other currently existing laws, are there any that could constrain the CROs to better performance? The only law specifically addressing CROs is Congress's effort from a few years ago, the Credit Rating Agency Reform Act of 2006 (CRARA), which was inspired by the corporate collapses of 2000-2001. ${ }^{140}$ CRARA is a pointedly free-market piece of legislation; it basically has two business ends, both devoted to decreasing concentration and improving price competition in the supply of ratings. First, its basic remedy for better credit-rating performance is simply to mandate the licensing of a larger number of NRSROs. ${ }^{141}$ Shortly after implementation of CRARA's new and more permissive licensing process in mid-2007, the Commission granted NRSRO status to a handful of new registrants. Second, CRARA directs the SEC to prohibit some CRO behavior by rulemaking. ${ }^{142}$ Congress directed the Commission to prohibit actions it "determines to be unfair, coercive, or abusive," but explicitly provided that the kinds of conduct to be prohibited should include specific exclusionary practices the majors had been accused of using to deter competition. ${ }^{143}$ Finally, to cement its market approach, CRARA explicitly prohibits the SEC from regulating the "substance" of credit rating itself and preempts any state law that would do the same. ${ }^{144}$

methodologies by consensus procedures. See Sagers, Twilight, supra note 133 (explaining the federal requirement of "consensus" standard setting). Affected parties could participate in making the methodologies better. The problem is again the very idea of private credit rating intermediaries. The CROs have access to neither more nor less substantive knowledge about prevailing finance economics theory than other participants, and they have not demonstrated any inherent comparative advantage over other market participants in predicting credit risk, despite their first-hand experience rating the vast majority of debt issues. Moreover, opening their processes in such a way as to make them consensus operations would presumably upset their profit-making business model substantially. So while consensus procedures might improve their methodologies to some extent, the question remains whether they could really add value that would justify their expense.

140. See supra note 9 .

141. By that statute Congress for the first time established a formal, objective process by which ratings entities could apply for NRSRO status, consistent with agitation by some for years that the real problem in credit rating has been lack of competition. See White, supra note 5 , at 52 (discussing SEC criteria for designating NRSROs).

142. 15 U.S.C. $\$ 78 o-7$ (i) (2006).

143. Id. $\S 780-7(\mathrm{i})(1)$.

144. CRARA sets a few other limits that are not directly competition-related, but they are flimsy and virtually afterthoughts. For instance, it requires an NRSRO to establish, maintain, and enforce policies and procedures "reasonably designed, taking into consideration the nature of the [NRSRO's] business . . and [that of] affiliated persons and affiliated companies thereof, to address and manage conflicts of interest." 15 U.S.C. $\$ 780-$ $7(h)(1)(2006)$ (emphases added). This provision is largely toothless, however, as the majors have all had formal ethical rules and internal conflict-of-interest controls for years, none of which prevented either the recent ratings disasters nor the gross abuses of the 
The hope is that ratings criteria will continue to be developed privately by market institutions and that the discipline of competition will improve not only the price of ratings but also their substantive quality. Although new amendments to these rules have been adopted ${ }^{145}$ and others remain pending, ${ }^{146}$ the major goal remains merely to increase competition, leaving both the development of ratings methodology and the judgment of particular CROs' performance to the market. ${ }^{147}$

Competition as a solution will not work. Admittedly, effective price competition may at least bring down ratings fees and encourage some greater concern for quality, but several major problems suggest that CRARA's approach will be of little value. First, licensing more NRSROs does not result in more competition. Those second-tier firms that managed to get pre-CRARA designation were just acquired by the majors in a relatively quick fashion. ${ }^{148}$ Competition authorities have seen little reason

structured-finance era. Neither CRARA nor the implementing regulations require any safeguards beyond those the majors already have in place.

145. See Amendments to Rules for Nationally Recognized Statistical Rating Organizations, 74 Fed. Reg. 6,456 (Feb. 9, 2009) (to be codified at 17 C.F.R. pts. 240 \& 249b) (amendments by SEC that went into effect in April 2009).

146. Proposals are still pending that would require ratings of structured securities either to use special ratings symbols or be published along with written reports, see Nationally Recognized Statistical Ratings Organizations, 73 Fed. Reg. 36,212 (proposed June 25, 2008), and, more significantly, proposals that would remove the use of the NRSRO references in securities regulations. See Amendments to Rules for Nationally Recognized Statistical Rating Organizations, 74 Fed. Reg. at 6,456 n.1 (referencing the several notices of proposed rulemaking in which these changes were proposed).

147. Specifically, the SEC's April 2009 amendments, see supra note 145, focus heavily on mandatory disclosures by the CROs of the accuracy of their own ratings over time. Commentators have urged such a requirement for some time, but it bears repeating that the Commission only requires disclosure of this information. It will remain for markets to determine whether to punish a given CRO for its bad performance, and no such thing has ever occurred, despite the many scandalous instances of poor CRO performance. Moreover, empirical evidence has existed for several decades examining the performance of the various CROs, and often explicitly comparing them. See supra notes 97-103. There is no reason to doubt that an empirical study of their performance will be any less available in the foreseeable future.

Admittedly, the new amendments and those still pending would add some other protections, including enhanced record-keeping requirements that might aid the Commission's increased examination efforts since the subprime meltdown. But it is hard to imagine that the added disclosure, record keeping, and conflict-of-interest rules will materially alter the internal rules that the CROs already maintain or the modest, additional requirements imposed by CRARA and the Commission's initial rules.

148. Even before CRARA, the SEC granted the designation to several firms outside of the three major firms, but each firm was either acquired or combined with another CRO within a few years, and all of them wound up eventually joining a major CRO. The Duff \& Phelps firm, which was designated in 1982, and McCarthy, Cristani \& Maffei, designated in 1983, merged in 1991 and then were acquired by Fitch in 2000. Thompson BankWatch, which enjoyed a limited designation for bank issues since 1992, was "upgraded" to generalpurpose designation in 1999 and then almost immediately it too was acquired by Fitch in 2000. IBCA, a London-based firm, received limited designation for bank issues in 1997 and 
to stop these moves, and one anticipates that given the authorities' basic theoretical approach to merger enforcement, the CRARA-engendered increase in the number of NRSROs will make it even easier for future acquisitions. While it is too early to predict the outcome of the CRARA experiment, there is no particular reason to believe those newly licensed NRSROs will not simply be acquired and will never meaningfully decrease concentration in the industry. Likewise, CRARA impliedly assumes that NRSRO designation is the market's only significant entry barrier. But smaller firms and new entrants face the significant problem of developing the very reputational capital that current NRSROs claim to be so central to their continued operation. ${ }^{149}$

Next, even if CRARA or some other legislative innovation managed to inject some price competition, there is no particular reason to believe that it will improve the quality of ratings. Competing CROs have existed for many years, both here and overseas, and while they are mainly much smaller than the major CROs, most of them do not charge issuer fees. ${ }^{150}$ Until recently none of them were NRSROs, and so all they had to sell to their subscribers was information in competition with the majors. Many of these firms rate large percentages of issues throughout bond markets or within particular segments. Given their numbers, the breadth of their coverage, and the major CROs' poor performance of the past few decades, some of those firms should have had some opportunity to outperform the major CROs. And given the speedy dissemination of information in capital markets, that superior information would have been widely available. Yet, the existence of that competition has had no discernable impact on the performance of the majors.

But finally, one completely different and possibly very significant problem with competition as a solution-especially as it is embodied in CRARA, which simply increases the number of firms entitled to sell NRSRO regulatory licenses to bond issuers-is that it will likely decrease the quality of ratings. In their role as NRSROs, the agencies act literally as regulators because issuers will adjust their behavior to standards devised by CROs if they deem it necessary for a desired rating. A nicely documented historical record shows that where regulators share overlapping oversight of the same regulated entities, they will often "compete" for their subjects'

then combined with Fitch in 1997. See White, supra note 5, at 46.

149. See TeChnical Comm., InT'L Org. OF SeCs. Comm'ns, Report on the Activities OF CREDIT RATING AGENCIES 14-15 (2003), available at www.fsa.go.jp/inter/ios/20030930/05.pdf, for an explanation of this problem.

150. As of 2003, the IOSCO Technical Committee found that dozens of overseas CROs were neither affiliated with the majors nor charging issuer fees. See id. at 9 . 
"business" by loosening their standards, ${ }^{151}$ and there is emerging empirical evidence that increased competition among CROs leads to ratings that are more "issuer friendly.", 52

\section{International and Self-Regulatory Initiatives}

Intergovernmental and nongovernmental organizations studying the problem have settled on one particular solution: the CROs' voluntary adoption of a hortatory code recently promulgated by International Organization of Securities Commissions (IOSCO) and the International Group of Treasury Associations (IGTA). ${ }^{153}$ Rules of this nature, however, were not made to work, which is made evident by the fact that all of the major CROs implemented the IOSCO code by early 2007, well before the day on which the major CROs inaugurated the subprime meltdown. ${ }^{154}$ Thus, even after their adoption of these codes, the majors rated extremely risky instruments very highly, in spite of evidence that they lacked confidence in their own ratings, and they did so under clear pecuniary conflicts of interest. ${ }^{155}$ Moreover, general hortatory conduct rules focusing on transparency and independence are beside the point in light of CRARA

151. In a careful study, Steven Ramirez showed that banks, in particular, who have long had their choice among various federal and state regulators, have played those regulators against one another, encouraging "regulatory competition" to achieve the most favorable regulation. See Steven A. Ramirez, Depoliticizing Financial Regulation, 41 WM. \& MARY L. REV 503 (2000). As he notes, regulatory experts recognized this problem as early as 1949. Id. at 534 (discussing U.S. COMM'N ON THE ORG. OF THE EXECUTIVE BRANCH OF THE GOV'T, THE HOOVER COMMISSION ON ORGanizaTION OF THE EXECUTIVE BRANCH OF THE GOVERNMENT (1949)). Other observers, prominently including the General Accounting Office, have, for this reason, urged consolidation of financial regulatory authorities for many years. See U.S. GeN. ACCOUNTING OfFICE, BANK OverSight: FundaMENTAL PRINCIPLES FOR MODERNIZING THE U.S. STRUCTURE 3-4 (1996). In the context of the CROs, the lack of meaningful government oversight or public accountability renders the regulatory competition problem potentially even more serious. For investigatory evidence of the CROs' "race to the bottom," see SEC 2008 STAFF REPORT, supra note 3.

152. Bo Becker \& Todd Milbourn, Reputation and Competition: Evidence from the Credit Rating Industry (Harvard Bus. Sch., Working Paper No. 09-051, 2008). An excellent example is that in one of the rare well-documented instances of actual head-to-head competition among major CROs, Fitch managed to steal substantial early market share in structured ratings. For a time, it was considered the dominant CRO in that niche. There is reason to believe Fitch competed not on price but by lowering its rating standards, and that Moody's and S\&P responded by lowering theirs. See Bolton et al., supra note 10 (reaching a similar result in a game theoretic model); Skreta \& Veldkamp, supra note 10, at 22.

153. See supra notes 5-6.

154. See Technical Comm., Int'l Org. OF Secs. Comm'ns, Review of IMPLEMENTATION OF THE IOSCO FUNDAMENTALS OF A CODE OF CONDUCT FOR CREDIT RATING AGENCIES 13 (2007). Though the majors did not adopt the IOSCO code verbatim, the Technical Committee found that each of them had "strongly implemented" almost all of it in their internal ethical codes. Id.

155. See supra note 56 and accompanying text (describing CROs' roles in the creation of the credit crisis). 
and its implementing regulations, which already mandate such things, and will have no effect in any event.

\section{Civil Liability}

Even if existing U.S. and international regulatory rules do not work, CROs might be made to perform better through more successful ex ante lawsuits. But, as Partnoy points out, "[t]he only common element" in lawsuits challenging CROs for incompetence or malfeasance "is that the rating agencies win." 156 This has been partly for the First Amendment reasons stated above, but as we will now show, even without that protection, they would remain substantially underconstrained for substantive legal reasons, both under the handful of theories that have actually been brought against them and as to other theories we were able to devise.

\section{Federal Securities Regulation}

The only major federal securities laws that could be relevant are the Investment Advisers Act of 1940 (IAA) ${ }^{157}$ and the Securities Exchange Act of 1934 (Exchange Act). ${ }^{158}$ First, the CROs were traditionally subject to the IAA and appeared to comply with it without too much complaint, ${ }^{159}$ even though a 1985 Supreme Court ruling probably exempts them from it for First Amendment reasons. ${ }^{160}$ But more recently, CRARA amended the Act to explicitly exempt NRSROs from coverage unless they issued recommendations on purchasing, selling, or holding securities. ${ }^{161}$ In any case, subjecting them to IAA liability would not be a desirable course of action, both because of the burden on the $\mathrm{SEC}^{162}$ and because of the fact that most CRO ratings are not the type of personalized investment advice

156. Partnoy, supra note 10 , at 79.

157. 15 U.S.C. $\S 80 \mathrm{~b}-1$ (2006).

158. Id. $\$ \S 78 \mathrm{a}-780 o$ (2006). The Securities Act of 1933 (Securities Act) is not terribly relevant. Securities Act Rule 436(g)(1) exempts NRSROs from $\S 11$ liability, and while $\S 17$ (a) has language similar to the anti-fraud provisions of Exchange Act Rule 10b-5, $\$ 17(\mathrm{a})$ applies only to "sellers" of securities.

159. See Memorandum from Anette L. Nazareth to William H. Donaldson, Chairman, SEC (June 4, 2003), available at http://www.sec.gov/spotlight/ratingagency/baker060403.pdf.

160. See Lowe v. SEC, 472 U.S. 181 (1985) (holding that a completely disinterested publication regularly offered to the general public falls within the 15 U.S.C. $\S 80 \mathrm{~b}-$ 2(a)(11)(D) exception to Advisors Act coverage).

161. See Credit Rating Agency Reform Act of 2006, Pub. L. No. 109-291, § 4(b)(3)(B), 120 Stat. 1329 (2006) (amending 15 U.S.C. $\$ 80 \mathrm{~b}-2(\mathrm{a})(11)$ ).

162. The SEC has sole authority to enforce most provisions of the Investment Advisors Act. See Transamerica Mortgage Advisors, Inc. v. Lewis, 444 U.S. 11, 14 (1979). 
that the Act seeks to regulate. ${ }^{163}$

Second, parties might seek liability under Exchange Act $\S 10(\mathrm{~b})$ and Rule 10b-5. ${ }^{164}$ However, a major hurdle will be proof of "a mental state embracing intent to deceive, manipulate, or defraud,"165 which at summary judgment must be shown by a "strong" inference. ${ }^{166}$ As Partnoy observes, the ratings are "extensively disclaimed and not ... recommendation[s] to buy, sell or hold securities."167 Without proof that a CRO had knowledge that would have changed the issued rating, it will not be liable for $\S 10(\mathrm{~b})$ violations.

\section{Antitrust}

The level of concentration in the U.S. ratings industry might seem to call for an antitrust solution, and for that reason CRARA includes a competition-policy approach. Not only have market watchers suggested an antitrust solution, but the Justice Department once almost brought suit, ${ }^{168}$ some others have sued ${ }^{169}$ and one state attorney general's federal antitrust suit remains pending. ${ }^{170}$

Antitrust will not work. First, a technical problem will confront antitrust claims before courts even reach the merits. There is a fairly solid chance that CRARA's oversight of the industry, and especially its evident insistence on expanded competition, actually preempts antitrust litigation

163. See generally Lowe, 472 U.S. at 190-91, 204, 207-08 (discussing the reasons why the Act was crafted).

164. 15 U.S.C. $\S 78$ j(b) (2006); 17 C.F.R. $\S 240.10$ b-5(b) (2008). Private claims have been brought against CROs as aiders and abettors of $\S 10$ (b) fraud, but the Supreme Court has twice shut the door on this theory. In Cent. Bank of Denver v. First Interstate Bank of Denver, N.A., 511 U.S. 164, 179-80, 190-91 (1994), the Court held that there is no private right of action for aiding and abetting a $\$ 10(\mathrm{~b})$ violation. The issue was raised again after the enactment of the Private Securities Litigation Reform Act of 1995, which gave the SEC authority to prosecute aiders and abettors of $\$ 10(\mathrm{~b})$ violations, and the Court again held that there was no private right of action. Stoneridge Inv. Partners, LLC v. Scientific-Atlanta, Inc., 128 S. Ct. 761, 768-69 (2008). The SEC may still prosecute such aiders and abettors, as $\S 104$ of the Private Securities Litigation Reform Act of 1995 gives the SEC authority to do so. Pub. L. No. 104-67, $\S 104,109$ Stat. 737, 757 (1995) (codified as amended at 15 U.S.C. $\S 78 \mathrm{t}(2006))$.

165. Ernst \& Ernst v. Hochfelder, 425 U.S. 185, 193, 194 n.12 (1976).

166. Tellabs, Inc. v. Makor Issues \& Rights, Ltd., 551 U.S. 308 (2007) ("To qualify as 'strong'... we hold, an inference of scienter must be more than merely plausible or reasonable - it must be cogent and at least as compelling as any opposing inference ....").

167. Partnoy, supra note 10 , at 79 . Opinions can be actionable as $\S 10$ (b) fraudulent statements, but it must be shown that the speaker does not believe the opinion and that the opinion is not well-founded. See, e.g., Mayer v. Mylod, 988 F.2d 635, 638-39 (6th Cir. 1993); In re Nat'l Century Fin. Enters., Inc., 580 F. Supp. 2d 630, 644 (S.D. Ohio 2008).

168. See supra note 8

169. See id. (discussing Jefferson County Sch. Dist. No. R-1 v. Moody's Investor's Servs., Inc., 175 F.3d 848 (10th Cir. 1999)).

170. See id. (discussing the pending suit by the Connecticut Attorney General). 
entirely. ${ }^{171}$ Even if it does not, an antitrust suit might also be fairly hard to bring as a substantive matter. Section 2 monopolization seems the only likely angle of attack because there is no obvious collaborative conduct, ${ }^{172}$ and it is not clear that even the majors' massive market shares would support such a claim. Moreover, with the exception of some conduct by Moody's that appears to have abated, ${ }^{173}$ it is hard to imagine how a plaintiff could establish the "exclusionary conduct" element of that cause of action. The major CROs will likely argue that their market power comes largely from government incorporation of their ratings. Of course, a Clayton Act $\S 7$ challenge to any of the many acquisitions that have kept the major

171. Where a federal statute makes clear Congress's intent that antitrust not apply to some particular activity, even in the absence of explicit language in the statute, a court may hold that antitrust is "implied[ly] repealed" as to that activity. In fact, in four leading opinions, the Supreme Court has held antitrust impliedly repealed as to securities markets by prevailing federal securities law. See Credit Suisse Secs. (USA) LLC v. Billing, 551 U.S. 264, 275 (2007); Gordon v. NYSE, 422 U.S. 659, 682, 685-86 (1975); United States v. Nat'l Ass'n of Secs. Dealers, Inc., 422 U.S. 694, 734 (1975); Silver v. NYSE, 373 U.S. 341, 357,371 (1963). By the Court's prevailing standard, antitrust will be held repealed as to some given activity if the antitrust complaint and the other federal law are "clearly incompatible." Credit Suisse, 551 U.S. at 275-76. The Credit Suisse Court, which considered this standard in the context of antitrust liability for conduct also subject to SEC regulation, strongly implied that there could be clear incompatibility wherever an antitrust complaint challenged activity that even someday might be subject to SEC regulation, merely authorizing conduct that otherwise would violate antitrust. Id. The SEC has power under CRARA to "prohibit any act or practice ... the Commission determines to be unfair, coercive, or abusive," and has already used it to prohibit certain anticompetitive practices that might otherwise have been evidence for a $\S 2$ monopolization plaintiff of "exclusionary conduct." See 15 U.S.C. $\S 780-7(\mathrm{i})(1) ; 17$ C.F.R. $\S 240.17 \mathrm{~g}-6(\mathrm{a})$. Moreover, while the SEC's rulemaking power under $\S 780-7$ (i) contains an explicit "savings clause" that preserves antitrust authority - that is, Congress directed that CRARA's oversight of the industry was not meant to "impliedly" repeal antitrust as to the CROs, see 15 U.S.C. $\$ 780-$ $7(i)(2)$-in the recent past the Supreme Court has read similar clauses completely out of existence. In Verizon Commc'ns Inc. v. Law Offices of Curtis V. Trinko, LLP, 540 U.S. 398, 411-15 (2004), the Court considered a $\$ 2$ monopolization claim against a phone company that refused to provide nondiscriminatory access to its phone-line facilities, despite a requirement in the Telecommunications Act of 1996 to do so. That Act even contained a savings clause providing that "nothing in this Act or the amendments made by this Act shall be construed to modify, impair, or supersede the applicability of any of the antitrust laws." Telecommunications Act of 1996, Pub. L. 104-104, $\S 601,110$ Stat. 56, 143 (codified as amended at 47 U.S.C. $\S 152$ note (2006)). The Court nevertheless refused to entertain plaintiff's antitrust claim on the ground that the Telecommunications Act already contained provisions mandating competition, weighing the costs and unlikely benefits that the Court believed to be promised by the $\S 2$ claim. Verizon, 540 U.S. at $411-15$. The Court said this was appropriate, noting, "[The] regulatory structure [was] designed to deter and remedy anticompetitive harm. ... [W]here, by contrast, '[t]here is nothing built into the regulatory scheme which performs the antitrust function,' the benefits of antitrust are worth its sometimes considerable disadvaritages." Id. at 412 (citation omitted).

172. Without some evidence of an anticompetitive agreement, neither $\S 1$ nor $\S 2$ conspiracy to monopolize liability will be available. 15 U.S.C. $\S \S 1-2(2006)$.

173. Specifically, Moody's apparently agreed with the Justice Department to no longer use unsolicited ratings as a punishment to issuers for failure to seek a Moody's rating. See supra note 8. 
CROs in a dominant position would require no exclusionary-conduct showing, and concentration in the industry ought to be large enough at least to raise Clayton Act concerns. Still, not only have all domestic CRO acquisitions of the past several years received regulatory approval, but they were almost all acquisitions by Fitch or even smaller firms. Fitch remains a distant third-place challenger to Moody's and S\&P, and the associated increases in concentration may be too small to challenge.

But more importantly, there is no especially promising reason to believe that even successful litigation against the CROs would remedy any problems of real concern. The best long-term benefit from any potential antitrust litigation would be increased price competition. For all the reasons mentioned in connection with CRARA, the entry of more CROs will not necessarily ensure either meaningful price competition or more accurate ratings.

\section{State Law}

State government regulation of CROs essentially does not exist, but if it did, it would face problems. CRARA specifically preempts all state or local registration, licensing, or qualification requirements for NRSROs. ${ }^{174}$ Although states can investigate and bring enforcement actions against NRSROs for fraud or deceit, ${ }^{175}$ CRARA also preempts any state or local regulation that regulates the "substance of credit ratings or the procedures and methodologies" NRSROs use to determine ratings. ${ }^{176}$ And given the international scope of the problem, state-by-state regulation hardly seems desirable. Prospective state-level regulation might also face the problem of CRO "retaliation" in that CROs might refuse to rate products originating in states with laws unfriendly to those products. This happened in Georgia in 2002 when that state passed an anti-predatory lending law. ${ }^{177}$

Issuers or investors might raise any number of state law tort claims to challenge inaccurate ratings. However, willful violations-such as defamation, fraud, and the like-would be difficult to prove in all but the most extreme cases ${ }^{178}$ and may also be barred by the First Amendment. ${ }^{179}$

174. 15 U.S.C. $\S 78 o-7(o)(1)(2006)$.

175. Id. § 78o-7(o)(2).

176. Id. $\$ 780-7(\mathrm{c})(2)$.

177. See Engel \& McCoy, supra note 109, at 2099; Christopher L. Peterson, Predatory Structured Finance, 28 CARDOZO L. REV. 2185, 2243-44 (2007); see also C. Lincoln Combs, Comment, Banking Law and Regulation: Predatory Lending in Arizona, 38 ARIZ. ST. L.J. 617, 628-29 (2006) (discussing the CROs' influence over a state anti-predatory lending law in Georgia).

178. Fraud claims encounter the same issues as Rule $10 \mathrm{~b}-5$ claims-the proof of scienter. That is, it is difficult to prove that CROs intended to defraud, because it is difficult to show that CROs had actual knowledge of some fact that would have changed the rating 
Negligence claims, such as negligent misrepresentation, have a better chance of surviving until trial but only in limited situations. ${ }^{180}$ Generally speaking the courts have found CROs owe no duty of care toward thirdparty investors when making ratings announcements public. ${ }^{181}$

\section{LIKELY FUTURE UNREGULABILITY}

\section{A. Real Free-Market Solutions: Adopt Investor-Pays or Displace Intermediation Altogether}

One solution is to get the CROs more or less out of the credit rating business. Markets themselves generate information, and public capital markets are thought to do it fairly efficiently. Thus, probably the best known CRO-reform proposal is Frank Partnoy's long-standing recommendation to remove the CROs from any regulatory role. He would retain both private and public portfolio rules for institutional investors, but would replace NRSRO ratings with yield spreads, which, he says, are already readily available and should in principle measure risk at least as well as the CROs or any other analytical intermediary. ${ }^{182}$

Although removing regulatory reliance upon credit ratings is an important first step, a significant problem with Partnoy's solution is that calculating and implementing enforceable yield spreads will be more difficult than Partnoy implies. But more significant is his strong, implicit

assigned to the debt issue. There has been some success suing CROs for fraud and negligent misrepresentation, but only in the most egregious cases. For example, when CROs conspire with hedge funds to provide false reports to depress issuer equity pricing, they may "step[] over the line into defamation and other torts." See Overstock.com, Inc. v. Gradient Analytics, Inc., 61 Cal. Rptr. 3d 29, 33-34 (2007) (denying defendant's motion to strike the complaint).

179. See supra notes 134-35 and accompanying text; see also Sagers, supra note 134.

180. See, e.g., In re Nat'l Century Fin. Enters., Inc., 580 F. Supp. 2d 630, 646-49 (S.D. Ohio 2008) (denying Moody's and Fitch's motions to dismiss claims for negligent misrepresentation when ratings were issued for a private placement and were assigned without the exercise of reasonable care).

181. See supra note 165 and accompanying text.

182. See Partnoy, supra note 11 , at 624 . One issue with relying on spreads instead of ratings is that spreads can vary significantly due to macroeconomic factors, just as they have in the wake of the recession of 2008. This is likely due to the fact that bond prices include more information than credit risk, which is supposed to be the sole concern of credit ratings. See generally Kose John et al., Credit Ratings, Collateral, and Loan Characteristics: Implications for Yield, 76 J. Bus. 371 (2003); Edwin Elton et al., Explaining the Rate Spread on Corporate Bonds, 56 J. FIN. 247 (2001); Edwin Elton et al., Factors Affecting the Valuation of Corporate Bonds, 28 J. BANKING \& FIN. 2747 (2004). A related suggestion, which would replace a simple letter-grade credit rating with underlying assumptions or market measures such as the assumed default probability, loss given default, etc., would likely have the same effect as removing credit ratings from regulation, because categories of ratings would become more complex and less clearly defined as "investment grade." 
free-market confidence. Despite what he implies, markets have sometimes measured risk poorly as it has with respect to the present crisis. However significant the role of the CROs and regulatory failures or any other particular factor may have been, one failure originating purely in capital markets themselves made a major contribution: long-standing, systematically underpriced risk premia. ${ }^{183}$ There is no particular reason to believe that such a thing will not happen again.

A related suggestion to better harness incentives is to keep private intermediaries but mandate a return to an investor-pays business model. Investors might be better trusted to decide how much information to buy. They would pose neither the agency costs of the current system (corporate managers might pay for more than an efficient amount of analytical services) nor conflicting interests. Furthermore, they might better penalize intermediaries that perform poorly. The problem will be overcoming the tremendous free-riding and collective-action problems it would pose, which may have led to the issuer-pays system. Some means would have to be devised by which individual investors could fund analysis by pooling their resources for it at low cost while overcoming the public-goods nature of the information they purchase. Devising such a system seems extremely complex and rife with uncertainties that are presently unknown and possibly unknowable. For instance, the voucher system proposed by Choi and Fisch raises more questions than answers, despite their long, elegant, and detailed treatment of the system. ${ }^{184}$ Such a system seems complex and costly enough to raise the question as to why it would not be better just to have the government act as the intermediary. ${ }^{185}$

\section{B. Other Market Solutions, Sort of: Skin in the Game and Investor- Controlled CROs}

Another market-based solution would be to retain an intermediary's analysis in portfolio rules, but to require that entity to have some stake in all the securities it rates. Obvious and critical problems would infect any proposal under which CROs themselves take pecuniary interests in rated

183. See FSF 2008 REPORT, supra note 5, at 5-6.

184. See generally Choi \& Fisch, supra note 14, at 314-44. Other suggestions for altering payment models pose similar difficulties. For example, one proposal that ratings be paid out of bond coupons poses a pair of problems. It may discourage CROs from rating debt that is below investment-grade because full ratings fees would not necessarily be paid when debt defaults. It may also encourage CROs to deflate ratings to increase the amount or the rate at which they get paid, due to the larger coupon. For obvious reasons, it may also discourage CROs from rating long-term debt, or raising the costs of rating such debt, due to the increased probability of default over short-term debt.

185. See infra notes $195-98$ and accompanying text. 
firms, ${ }^{186}$ but one more-elegant alternative would be to do away with ratings as such and instead give the job to insurers. Any such proposal would presumably resemble the Enron-era suggestion of Sean Ronen, an NYU accounting professor, that a system of "financial statement insurance" replace the auditing of publicly disclosed financial statements. ${ }^{187}$ There is some reason to believe that parties with more skin in the game outpredict those who have less to lose. For example, some tentative empirical results show that professional short sellers have outperformed the market in predicting corporate accounting restatements. ${ }^{188}$

A solution proposed by Stanford law professor Joseph Grundfest at a recent SEC Roundtable event on CROs would involve the creation and mandatory utilization of investor-owned and controlled CROs (IOC CROs). ${ }^{189}$ Issuers would continue to pay for credit ratings, but in addition to the ratings they purchase now, they would have to pay for an IOC CRO to rate their issue as well. This model, which is reminiscent of the independent research requirement of the Global Legal Settlement following the recent accounting scandals, would not solve the significant lack of price competition in the CRO market. While it would ensure that the major CROs have a counterpart that would be designed to have an opposing bias, it is not clear that this would improve the quality of ratings sufficiently to justify the added expense.

But there remains a major problem with both ideas, at least until there is better empirical evidence on how self-motivated market observers work and when they are likely to fail. Major players with plenty of skin in various games performed very poorly both in the present crisis and in other recent ones. Large institutional investors, for example, have expertise and

186. Namely, (1) the intermediary would then have much bigger conflicts of interest, and (2) the major CROs rate far too many issues for them to invest in each one.

187. Ronen first suggested the idea in a New York Times op-ed piece. Joshua Ronen, Op-Ed., A Market Solution to the Accounting Crisis, N.Y. TIMES, Mar. 8, 2002, at A21. This was later elaborated with two coauthors. Alex Dontoh et al., Financial Statements Insurance 2 (NYU Stern Sch. of Bus., Working Paper, 2004), available at http://ssrn.com/abstract $=303784$.

188. See COFFEE, supra note 14 , at 35-36 \& n.76 (discussing evidence that a particular short-selling firm predicted the Enron collapse before any other observer and citing preliminary empirical evidence of similar performances by other short sellers).

189. See SEC, Transcript of Roundtable to Examine Oversight of Credit Rating Agencies 192-204 (April 15, 2009) (remarks of Joseph Grundfest), available at http://www. sec.gov/spotlight/cra-oversight-roundtable/cra-oversight-roundtable-transcript.txt.

A different restriction arising from the accounting scandal at the turn of the century, requiring firms to rotate their use of accounting agencies, could effectively create some price competition. Requiring issuers to use a CRO for no longer than a limited period of years, then subsequently preventing them from using that CRO for the same number of years, could foster a cottage CRO industry. Of course, it could also just encourage issuers to alternate between the major CROs and do away with the two-ratings norm for every issue. 
maintain their own in-house analytical capacity. Yet they failed to predict the subprime meltdown; indeed, they consumed securitized subprime assets voraciously right up until Pearl Harbor Day. Admittedly, there are reasons to believe that some institutional fund managers might continue buying a security even when they predict that it is overpriced, ${ }^{190}$ but in this case they failed to heed plenty of advance warning of very dire consequences.

Other sophisticated investors made this same mistake. American International Group (AIG) and others exposed themselves extensively through guaranteeing a "non-insurance" subsidiary's credit default swaps (CDSs). Indeed, the massive wave of RMBS downgrades was the triggering event in numerous AIG CDSs, which eventually led to government intervention to keep AIG afloat. Similarly, insurers who provided credit enhancements to RMBS pools by insuring pieces of them were taken by surprise when default rates soared. Thus, it is not clear that replacing CROs with insurance companies would materially improve risk estimation. ${ }^{191}$

\section{The Last Market Solution, We Promise: Internalize Risk Externalities}

It is commonly thought that the moment after a regulation takes effect the private sector finds ways around it. As discussed, some attribute financial innovation itself as merely a response to regulation. When markets practice this avoidance behavior, regulations should seek to align market incentives to encourage the market to police itself. This course of action has worked most effectively in the regulation of financing consumer purchases of goods and services, where the government has placed liability on loan purchasers to ensure that they police the individuals from whom they purchased loans.

In the CRO market, the entities that could exert the necessary pressure on CROs are limited to the investment banks that select which CRO will rate the debt issues they underwrite. It is unclear if making debt underwriters liable to investors for overinflated ratings will have the desired corrective effect. While loan purchasers in consumer markets had knowledge of the unlawful practices of loan originators, debt underwriters may have little knowledge of or control over the underlying assumptions the CROs use in their quantitative modes that lead to overinflated ratings. There is one obvious benefit of this proposal: it should limit the effect of the conflict of interest that leads to ratings inflation by forcing underwriters to bear a corresponding cost for such actions.

190. See supra note 121 and accompanying text (discussing evidence of "herding").

191. A fortiori, Partnoy's suggestion that reliance be made on the market for CDSs seems, in light of recent events, too risky. See Partnoy, supra note 11, at 679. 
This upstream liability would have an interesting effect on financial innovation by counterbalancing the underwriter's financial incentive to sell as much as possible with the potential cost of liability. The problem is that risks of liability imposed by way of federal securities law have failed massively during the past few decades, and it is not clear whether they ever much improved capital market efficiency even when enforcement worked better. Moreover, while underwriter liability should prevent the reckless adoption of financial innovations, it has the downside of likely increasing the cost of innovation.

\section{Anti-market Solutions: Substance Regulation or Outright Socialization of Analytical Intermediation}

An obvious approach is simply to increase the regulation of CROs and, in particular, to regulate the substance of what they do. This has never been done before, and for the time being, the primary CRO regulator is prohibited by federal statute from doing so-at least as to the NRSROs, CRARA prohibits it. ${ }^{192}$ But the air presumably is ripe for some reversal on that point and suggestions abound for it. The Congressional Oversight Panel, for example, made a comparatively drastic recommendation. The Panel proposed a public "Credit Rating Review Board" that could "sign off on any rating before it took on regulatory significance"- that is, before it would have the effect that NRSRO ratings have currently. ${ }^{193}$

The problem is that even in light of the current window during which regulation might be politically feasible, the Panel's recommendation would be extremely expensive and duplicative. The majors each rate on the order of 20,000 new issues per year, and the Credit Rating Review Board would presumably have to duplicate their work to some large extent. Under such a scheme, the natural question would be why the government does not simply do the job itself. Alternative oversight schemes that would be less costly because of reduced scope of oversight would be substantially less effective. For example, the Congressional Oversight Panel alternatively suggested structuring its Review Board as a licensure and oversight body, like the Public Company Accounting Oversight Board (PCAOB). ${ }^{194}$ But PCAOB has hardly been a model of regulatory success.

That then leaves what is probably the least politically feasible

192. CRARA provides, "Notwithstanding any other provision of law, neither the Commission nor any State (or political subdivision thereof) may regulate the substance of credit ratings or the procedures and methodologies by which any nationally recognized statistical rating organization determines credit ratings." 15 U.S.C. $\S 780-7$ (c)(2) (2006).

193. COP REPORT 2009, supra note 4, at 44.

194. See id. 
alternative, which may be undesirable for other reasons: the government itself might simply rate private debt-either in competition with the CROs or in legally preemptive usurpation of them. ${ }^{195}$ One benefit of a government informational intermediary is that it could charge user fees to issuers or investors, thereby solving both the public-goods nature of informational producers and the agency-cest problems sometimes said to affect intermediary services. ${ }^{196}$

Even aside from its patent absurdity from a political perspective-this solution would entail essentially killing off a multibillion-dollar industry and would be greeted as outright socialist treachery-a government informational intermediary would require a very costly new apparatus. Also, whatever might be its other costs and benefits, this approach is at odds with two other existing federal policies. First, the federal government has essentially prohibited itself from making any new "standard" where a "voluntary consensus standard" is available from the private sector that would do the job. ${ }^{197}$ Likewise, by executive order dating to the Eisenhower Administration, the White House has consistently prohibited federal agencies from producing goods or services in competition with those available in the private sector. The policy is now codified federal law. ${ }^{198}$

195. See, e.g., White, supra note 10, at 14-15; Roger Lowenstein, Triple-A Failure: How Moody's and Other Credit-Rating Agencies Licensed the Abuses that Created the Housing Bubble-and Bust, N.Y. TIMES, Apr. 27, 2008, (Magazine), at 36, 39, 41 (stating that by adopting the NRSRO approach, "[i]n effect, the government outsourced its regulatory function to three for-profit companies" and suggesting that "if the Fed or other regulators want[] to restrict what sort of bonds could be owned by ... anyone . . in need of protection, they would have to do it themselves-not farm the job out to Moody's").

196. See Choi \& Fisch, supra note 14, at 317-18.

197. Though the policy had various antecedents going back several years, it was formalized in the National Technology Transfer and Advancement Act of 1995, Pub. L. No. 104-113, § 12(d), 110 Stat. 775, 783 (1996) (codified as amended at 15 U.S.C. $\$ 272$ note (2006)), and implemented by Federal Participation in the Development and Use of Voluntary Consensus Standards and in Conformity Assessment Activities, 63 Fed. Reg. 8,546, 8,553 (Feb. 19, 1998). See also supra note 137 and accompanying text. See generally Sagers, Twilight, supra note 133.

198. The policy originated in an order of the Bureau of the Budget (predecessor to the Office of Management and Budget) under Eisenhower. See BuREaU OF THE BUdGeT, EXecutive OfFICE OF THE PREsIDENT, Bulletin No. 55-4 (1955) ("[T]he Federal Government will not start or carry on any commercial activity to provide a service or product for its own use if such product or service can be procured from private enterprise through ordinary business channels."). It has been in force continuously since then, codified for some decades now in OfFICE OF MGMT. \& BUDGeT, CiRCUlAR A-76 (2003), and supplemented by the Federal Activities Inventory Reform Act of 1998, Pub. L. No. 105-270, 112 Stat. 2382 (1998) (codified as amended at 31 U.S.C. $\$ 501$ note (2006)). Its current thrust is that (1) federal agencies may never engage in "commercial" activities where the good or service in question is available from the private sector, and (2) they must conduct periodic reviews of their in-house activities to determine whether any of them ought to be farmed out. See generally Steven L. Schooner, Competitive Sourcing Policy: More Sail than Rudder?, 33 PUB. CONT. L.J. 263, 271-73 \& n.39 (2004). 


\section{TENTATIVE CONCLUSIONS}

Two policy objectives now dominating the CRO debate are to reduce systemic risk and to improve capital-market pricing efficiency. Those goals are not currently being met. There is no reason, given the nature of their business model and the financial pressures they face, to believe that the CROs will at any foreseeable time be able to operate on an issuer-pays basis without significant conflicting pecuniary interest. Furthermore, there is no reason to expect the substantive quality of their work to improve in such a material way that catastrophic failures like the present one will not occur again soon. Moreover, there is no reason at present to expect that any policies currently in place-including those voluntarily adopted by the CROs, those required by CRARA and its implementing regulations, and civil liability rules enforceable by private plaintiffs or government enforcers-will achieve either of these goals. For these reasons, it is imperative that policymakers end their regulatory reliance upon the CROs, even though doing so will not fix the CRO market.

It seems likely that some significant regulatory change will come fairly soon. Also, given the small number of major CROs and that several major intergovernmental bodies have worked on this in close collaboration-the SEC, the U.S. Congressional Oversight Panel, the Basel Committee's Technical Committee, the International Organization of Securities Commissions (IOSCO), the Committee of European Securities Regulators, the International Group of Treasury Associations (IGTA), and so on-it seems likely that whatever will happen will be internationally coordinated. Therefore, the most likely outcome is that a code consisting of the IOSCO and IGTA codes will be internationally adopted. Those rules will be augmented by some regulatory enhancements in the United States. But given that the SEC has already proposed somewhat tougher new regulations under CRARA ${ }^{199}$ and has not requested new statutory authority, the likely U.S. response will simply be a tightening of existing rules to increase competition and improve transparency. We may see adoption of a CRO oversight body set up like the PCAOB, but it is hard to imagine its role will be anything more than a fairly passive one.

The analysis here suggests that these likely reforms will not be terribly successful. Capital asset pricing should be roughly as efficient as it was before. More importantly, none of these reforms has much hope of reining in the systemic risk of which we have already been victims, and importantly, they do nothing directly to constrain another $\mathrm{CRO}-$ issuer

199. See Nationally Recognized Statistical Rating Organizations, 73 Fed. Reg. 36,212 (proposed June 25, 2008) (to be codified at 17 C.F.R. pts. 240 \& 249b). 
partnership in lucrative innovative products like those of the structured finance era. But the analysis here also suggests that it may be quite hard to devise any regulatory approach that could constrain these sorts of problems without posing high costs and inviting new and unforeseen problems of its own. More-radical solutions have problems of political infeasibility. In short, capital markets currently contain a much more serious institutional flaw than has been recognized. 